\title{
The roles of vicariance and isolation by distance in shaping biotic diversification across an ancient archipelago: evidence from a Seychelles caecilian amphibian
}

Simon T. Maddock ${ }^{1,2,3,4^{*}}$ (D), Ronald A. Nussbaum, Julia J. Day ${ }^{3}$, Leigh Latta ${ }^{6}$, Mark Miller ${ }^{7}$, Debra L. Fisk ${ }^{8}$, Mark Wilkinson ${ }^{2}$, Sara Rocha ${ }^{9,10}$, David J. Gower ${ }^{2}$ and Michael E. Pfrender ${ }^{11}$

\begin{abstract}
Background: Island systems offer excellent opportunities for studying the evolutionary histories of species by virtue of their restricted size and easily identifiable barriers to gene flow. However, most studies investigating evolutionary patterns and processes shaping biotic diversification have focused on more recent (emergent) rather than ancient oceanic archipelagos. Here, we focus on the granitic islands of the Seychelles, which are unusual among island systems because they have been isolated for a long time and are home to a monophyletic radiation of caecilian amphibians that has been separated from its extant sister lineage for ca. 65-62 Ma. We selected the most widespread Seychelles caecilian species, Hypogeophis rostratus, to investigate intraspecific morphological and genetic (mitochondrial and nuclear) variation across the archipelago (782 samples from nine islands) to identify patterns and test processes that shaped their evolutionary history within the Seychelles.

Results: Overall a signal of strong geographic structuring with distinct northern- and southern-island clusters were identified across all datasets. We suggest that these distinct groups have been isolated for ca. 1.26 Ma years without subsequent migration between them. Populations from the somewhat geographically isolated island of Frégate showed contrasting relationships to other islands based on genetic and morphological data, clustering alternatively with northern-island (genetic) and southern-island (morphological) populations.

Conclusions: Although variation in H. rostratus across the Seychelles is explained more by isolation-by-distance than by adaptation, the genetic-morphological incongruence for affinities of Frégate $H$. rostratus might be caused by local adaptation over-riding the signal from their vicariant history. Our findings highlight the need of integrative approaches to investigate fine-scale geographic structuring to uncover underlying diversity and to better understand evolutionary processes on ancient, continental islands.
\end{abstract}

Keywords: Adaptation, AFLPs, Biogeography, Caecilian, Evolution, Islands, Morphology

\footnotetext{
* Correspondence: s.t.maddock@gmail.com

'Present address: Faculty of Science and Engineering, University of

Wolverhampton, Wolverhampton WV1 1LY, UK

${ }^{2}$ Department of Life Sciences, The Natural History Museum, London SW7

$5 B D$, UK

Full list of author information is available at the end of the article
}

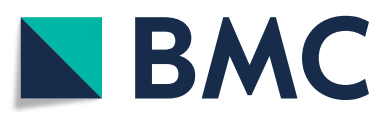

(- The Author(s). 2020 Open Access This article is licensed under a Creative Commons Attribution 4.0 International License, which permits use, sharing, adaptation, distribution and reproduction in any medium or format, as long as you give appropriate credit to the original author(s) and the source, provide a link to the Creative Commons licence, and indicate if changes were made. The images or other third party material in this article are included in the article's Creative Commons licence, unless indicated otherwise in a credit line to the material. If material is not included in the article's Creative Commons licence and your intended use is not permitted by statutory regulation or exceeds the permitted use, you will need to obtain permission directly from the copyright holder. To view a copy of this licence, visit http://creativecommons.org/licenses/by/4.0/. The Creative Commons Public Domain Dedication waiver (http://creativecommons.org/publicdomain/zero/1.0/) applies to the data made available in this article, unless otherwise stated in a credit line to the data. 


\section{BACKGROUND}

Islands have had an important influence on the understanding of diversification and adaptive evolution since the landmark publication of "On The Origin of Species by Means of Natural Selection" [1] see [2]. These systems have been the focus of numerous evolutionary studies in part because they are particularly tractable for investigating the consequences of evolutionary processes such as random genetic drift, founder effects and local adaptation e.g. [3-7]. The majority of these studies have focused on relatively rapidly evolving radiations on emergent oceanic island groups, such as Caribbean Anolis lizards e.g. [8-11], Galápagos finches e.g. [12-14], and Hawaiian spiders e.g. [15]. In contrast, there have been few studies investigating the effects that these evolutionary processes might have on lineages evolving on ancient continental islands, which are characterized by much greater timescales and likely lower overall vagility of resident taxa. To increase our understanding of evolutionary patterns and processes on ancient continental islands, we focus on a caecilian amphibian species endemic to the granitic Seychelles.

The Seychelles Archipelago comprises approximately 115 islands in the western Indian Ocean. The 41 granitic islands lie ca. $1500 \mathrm{~km}$ east of mainland East Africa (centered around $55^{\circ} 30^{\prime} \mathrm{E}$ and $4^{\circ} 30^{\prime} \mathrm{S}$ ) and provide a rare example of oceanic islands supporting multiple lineages of insular amphibians. The remaining 74 islands are of more recent coralline origin and are devoid of amphibians. The granitic islands are of continental origin [16], and are mountain-top remnants of the largely submerged Seychelles Microcontinent ("Seychellea" of [17]) that once formed part of the supercontinent Gondwanaland. These ancient remnants were isolated by the separation from Africa of a landmass (Indigascar of [18]) consisting of Madagascar, Seychelles and India [19-24]; with the Seychelles becoming fully separated approximately 65-62 Ma [24, 25]. Much of the Seychelles Microcontinent, comprising the exposed (ca. $250 \mathrm{~km}^{2}$ [26]) and submerged granitic Seychelles, currently lies submerged at a mean depth of $55 \mathrm{~m}$ and encompasses an area of $129,650 \mathrm{~km}^{2}$ [27]. Throughout their history, the individual granitic islands of the archipelago have been variously connected and sundered by eustatic sea level changes, and the Seychelles Microcontinent was likely maximally emergent as recently as 10 kya [28-32]. The granitic Seychelles are considered the emergent parts of an isolated continental block [33].

Despite the key attributes of the Seychelles system such as its continental origin, truly oceanic setting, and mosaic of ancient (including Gondwanan relictual) lineages and more recent overwater arrivals that make it attractive for studying evolutionary processes, the Seychelles biota remains poorly studied at the intraspecific level. Greater use of molecular techniques has underpinned a recent increase in the number of studies of phylogeographic patterns in the Seychelles [34-48]. These studies have documented some common e.g. $[40,49]$ and some different $[36,50]$ spatial patterns of genetic diversity, including 'cryptic' diversity within some taxa. In many taxa within the Seychelles (lizards $[39,44-46,51,52]$, frogs $[40,48]$ and crabs [47]) there is a broadly similar pattern of geographic structuring, with distinct northern vs. southern island group lineages. Generating comparative data for additional taxa, especially for phylogenetically and ecophenotypically disparate lineages and for taxa that have been resident in the Seychelles for varying durations, might allow common patterns of genetic and phenotypic variation to be identified. These analyses should enable more powerful tests of hypothesized biotic and abiotic causes of evolution within this ancient continental island system.

Seychelles is home to eight currently recognized species of caecilian amphibians (Gymnophiona) in three genera [53-55], belonging to a single, monophyletic radiation which has likely been isolated from confamilals since the Seychelles separated from India [25]. The presence of endemic amphibians (especially caecilians) on oceanic islands is highly unusual, and supports the hypothesis that the Seychelles Microcontinent has been at least partly emergent throughout the Cenozoic Era (see [56]). Here, we focus on Hypogeophis rostratus [57] because it is the most widespread endemic amphibian in the Seychelles, occurring on 10 of the granitic islands [56]. Phylogenetic relationships among Seychelles caecilians remain incompletely resolved, including identification of the closest extant relative of $H$. rostratus $[38,55]$. However, analyses of a previously published dataset [25] using the same methods reported in that study found that, applying nine different calibration strategies, estimated (mean) ages of splits among sampled extant species of Hypogeophis and Grandisonia are in the range of $16.4-27.9 \mathrm{Ma}$ (95\% posterior density ranges 11.0-37.5 Ma) (D. San Mauro, pers. comm.). Hypogeophis rostratus resides in a variety of habitats and elevations and is often found in high abundance in human altered habitat such as coconut plantations and gardens (pers. obs.). Although it can be seen in streams and pools, typically at night, $H$. rostratus is largely terrestrial and soil dwelling as adults, lays terrestrial eggs, has direct development [58, 59] and exhibits geographically structured morphological variation [60-62]. Despite the large range and seemingly adaptable nature of $H$. rostratus, the species is assumed to be less vagile (at least among islands) than many other Seychelles species that have been investigated phylogeographically (e.g. lizards) because it is largely fossorial and because of the osmotic properties of amphibian skin e.g. [63, 64], which make it intolerant of salt water [65]. 
Patterns of morphological diversity do not always represent phylogeny because factors such as local ecological adaptation and phenotypic plasticity can play a role in shaping phenotypic variation e.g. [66], including at the intraspecific level [67-69]. To understand evolutionary patterns and processes it can therefore be beneficial to analyze both genetic and morphological data. Few biologists have examined morphological or molecular intraspecific variation in caecilians across the Seychelles or elsewhere. Recent intraspecific studies of caecilians have generally been based on small sample sizes and/or have made only brief comments on morphology [70-73]. The three largest studies of intraspecific genetic and morphological variation in caecilians published to date are dominated by molecular data. Gower et al. [74] reported little variation and slight geographic structuring of mtDNA variation within the Indian ichthyophiid Ichthyophis bombayensis across a large area of peninsular India. Stoelting et al. [75] reported substantial, geographically structured morphological and mtDNA variation within the dermophiid Schistometopum thomense on the small Gulf of Guinea island of São Tomé. Wang et al. [76] reported substantial, geographically structured mtDNA and nuclear microsatellite variation in the ichthyophiid $I$. bannanicus in Indochina.

Here we present results of analyses of morphological and genetic variation in $H$. rostratus from across its range, representing the largest, most detailed examination of caecilian intraspecific variation to date. The primary questions we address are: what are the main patterns of genetic and phenotypic variation within $H$. rostratus across the Seychelles archipelago, and what processes are responsible for them?

\section{Results}

\section{Molecular data}

\section{Mitochondrial and nuclear DNA sequence data}

Based on variation in $700 \mathrm{bp}$ of the mitochondrial encoded cytochrome b gene (cytb) we identified 34 unique haplotypes among $100 \mathrm{H}$. rostratus individuals sampled from nine islands. Cytb data was partitioned into codon positions $(\mathrm{CP})$ based on the results of PartitionFinder [77] analysis, and for the Bayesian inference (BI) analyses run through MrBayes [78] using the substitution models $\mathrm{HKY}+\mathrm{I}$ (CP1), HKY (CP2) and GTR (CP3). Phylogenetic analyses using BI revealed a strongly supported, basal split between specimens from the northern islands + Frégate and specimens from the southern islands (Fig. 1a). The clustering pattern in the $c y t b$ phylogeny is congruent with the $c y t b$ haplotype network (Fig. 1b). The sharing of some haplotypes between islands could be indicative of shared ancestry (with recent vicariance not yet reflected in the molecular markers) and/or of some migration having occurred in the recent past between islands.
Northern + Frégate island vs. southern island individuals are separated by $p$-distances of $3.2-4.8 \%$ (between group mean distance $=3.7 \%$; net between group distance $=3.4 \%$ : Table 1 ). The maximum amount of genetic variation within the two main lineages is greater within the southern island group ( $p$-distances up to 1.6\%: between individuals from the island of Mahé) than within the northern + Frégate group ( $p$-distances up to $1 \%$ : between individuals from La Digue and Praslin).

Four nuclear loci-pro-opiomelanocortin (pomc), brain-derived neurotrophic factor $(b d n f)$, and two anonymous nuclear markers (brev5 and rost5 [79];)-were sequenced for a subset of the samples sequenced for $c y t b$ (Additional file 2). As expected, mtDNA nucleotide diversity is greater than for nuDNA (see Table 1). No nuclear haplotypes for $H$. rostratus are restricted to single islands or larger within-island regions except for the samples from Frégate for brev5 (Fig. 2). For brev5 there is a widespread northern island haplotype and a widespread southern island haplotype. Specimens from the eastern island of Frégate and one specimen from the northern island of Curieuse are more similar to southern island individuals. For pomc there are main northern + Frégate and southern-island clusters, though samples from the southern island of Cerf share alleles with two widespread northern island haplotypes; a pattern also observed in the widespread northern island haplotype for rost5. For bdnf and rost5, allele sharing is extensive and there are no clear distinctions between specimens from northern- and southern- island groups. For pomc, specimens from the islands of Mahé, Silhouette and St. Anne all have unique haplotypes.

Inference under the isolation with migration (IM) model [80] supports that no migration is occurring between the northern island + Frégate and southern island groups (Additional File 3). StarBEAST analyses estimate that the northern island + Frégate and southern island groups diverged approximately $1.26 \mathrm{Ma}$ [95\% HPD: $0.49-2 \mathrm{Ma}$ ] for the Yule tree prior (1.11 Ma [95\% HPD: 0.37-1.84 Ma] for the Birth Death tree prior, and 1.27 Ma [95\% HPD: 0.51-2.03 Ma] under a Coalescent tree prior).

\section{AFLP analyses}

AFLP genetic diversity varies considerably among islands. Using Nei's [81] unbiased heterozygosity, diversity estimates ranged from $\sim 0.19$ (Mahé) to $\sim 0.04$ (Praslin) (Table 2). Analyses of AFLP data identified considerable genetic structuring among islands. Estimates of $\theta$ were large, and $95 \%$ confidence limits of $\theta$ did not overlap with zero $(\theta=0.3574$; upper $\mathrm{CI}=0.4548$, lower $\mathrm{CI}=0.2670$ ).

In all STRUCTURE [82] analyses the optimal clustering of individuals was $K=2$. Clusters reflect a northern 


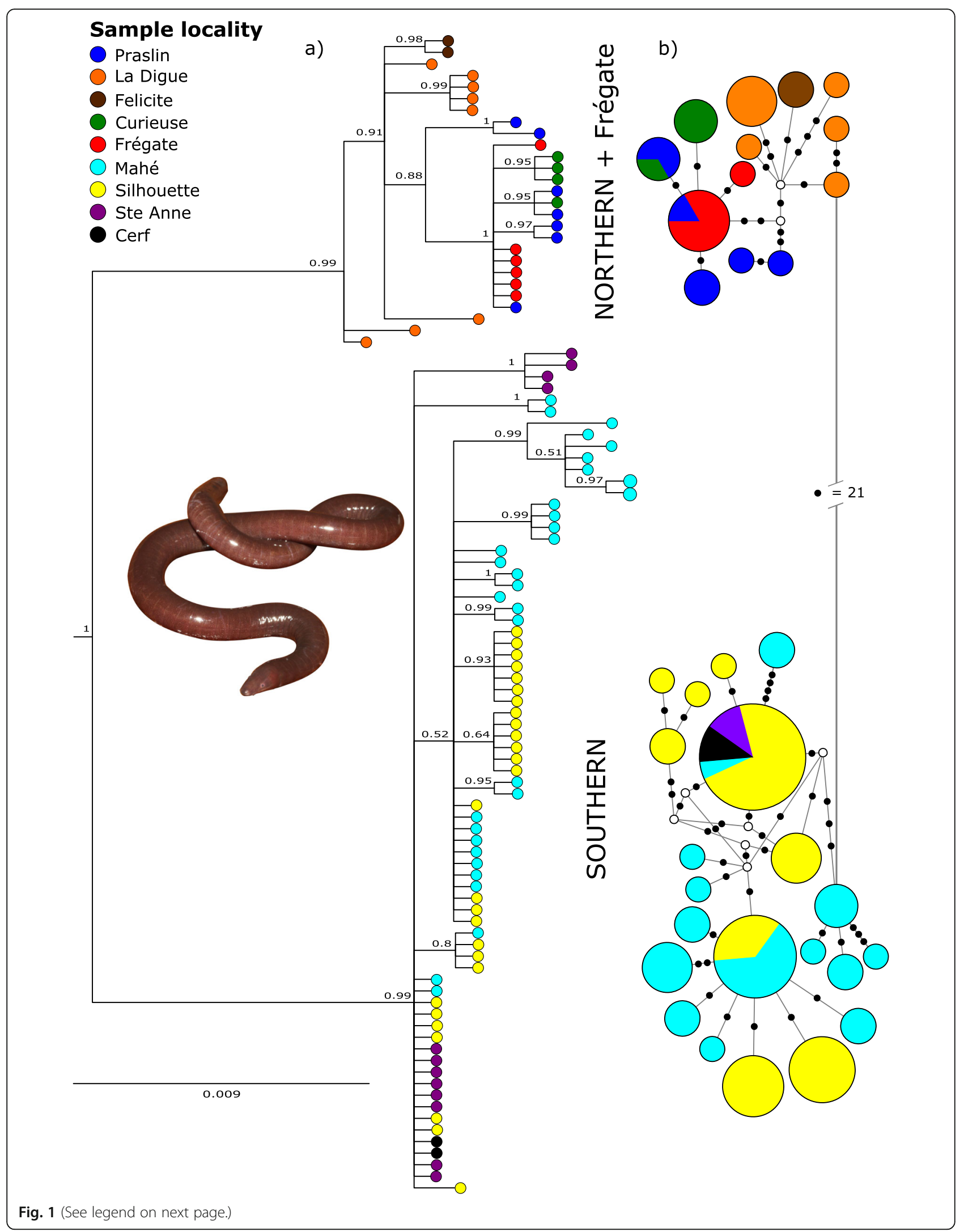


(See figure on previous page.)

Fig. 1 Evolutionary relationships of Hypogeophis rostratus inferred from cytb data: a) Bayesian inference majority rule consensus tree. BI posterior probabilities $>0.5$ are presented on the branches; $\mathbf{b}$ ) Median-Joining haplotype network. Size of the haplotypes are indicative of number of individuals in the haplotype. Small black circles refer to mutational steps between haplotypes and open circles represent extinct or unsampled haplotypes. a \& b) Colors on tips of the BI tree and within the haplotypes refer to sample island of origin as referred to in the key (and are the same as those used in Fig. 2). Depicted image of H. rostratus is from Mahé

+ Frégate vs. southern island group split (Fig. 3). Variation within the northern + Frégate island group is further divided into specimens from the northern islands (Praslin, Curieuse and La Digue) and Frégate (Fig. 3b), with one individual from Curieuse reflecting admixture between the two clusters. Within the southern-island group there is an east-west geographic subdivision of genetic variation $(K=2)$, with individuals from Silhouette and individuals from the closer islands of Mahé and Sainte Anne forming separate clusters (Fig. 3c). Some individuals from each island show small levels of admixture. Within Mahé additional structuring was found (Fig. 4), with a separation between specimens from the most northerly (Bel Ombre, Le Niole, St. Louis, Mt Simpson Estate) and most southerly (Anse Forbans) sampled localities showing very little admixture. The somewhat intermediate (although still northerly) samples (Mt. Coton and Foret Noire) have shared alleles with both the northernmost and southernmost populations, in a clear geographic gradient.

UPGMA and PCA analyses further indicate that the relatively high levels of AFLP structure are explained primarily by the presence of two island groups (Additional file 1), the maximally supported southern islands group (samples from Mahé, Silhouette, Sainte Anne),

Table 1 Nucleotide diversity

\begin{tabular}{llllll}
\hline & $c y t b$ & bdnf & pomc & brev5 & rost5 \\
\hline All islands & 0.019 & 0.001 & 0.006 & 0.008 & 0.004 \\
Northern group & 0.006 & 0.000 & 0.004 & 0.008 & 0.002 \\
Southern group & 0.005 & 0.001 & 0.005 & 0.000 & 0.004 \\
Praslin & 0.004 & 0.000 & 0.004 & 0.000 & 0.002 \\
La Digue & 0.004 & 0.000 & - & 0.004 & 0.002 \\
Curieuse & 0.001 & 0.000 & 0.005 & 0.020 & 0.004 \\
Felicite & 0.000 & 0.001 & 0.003 & 0.000 & 0.002 \\
Frégate & 0.000 & 0.000 & 0.003 & 0.003 & 0.002 \\
Mahe & 0.006 & 0.001 & 0.003 & 0.000 & 0.003 \\
Silhouette & 0.004 & 0.000 & 0.007 & 0.000 & 0.004 \\
Ste. Anne & 0.003 & 0.001 & 0.005 & 0.000 & 0.004 \\
Cerf & 0.000 & 0.001 & 0.003 & 0.000 & 0.002 \\
North vs south & 0.039 & 0.000 & 0.007 & 0.013 & 0.004 \\
D & 0.240 & -1.869 & -0.475 & 0.021 & -0.411 \\
\hline
\end{tabular}

Nucleotide diversity of genetic sequence data for 100 (100 cytb, 25 bdnf, 19 pomc, 26 brev5, 25 rost5) Hypogeophis rostratus individuals, with mean $p$ distance between northern and southern island groups and Tajima D's and a much less strongly (60\% bootstrap) supported northern islands (Praslin, Curieuse, La Digue) + Frégate group. Within the northern island + Frégate group there is a strongly supported ( $92 \%$ bootstrap) group comprising samples from Praslin, Curieuse, and La Digue (to the exclusion of Frégate). In the PCA plot (Additional file 1) there is substantial overlap among samples from the southern islands and among samples from the northern islands; the Frégate island population is completely distinguishable. Consistent with our UPGMA dendrogram, estimates of $\theta_{\mathrm{ST}}$ obtained from these two main island groups (southern and northern + Frégate) are similar to overall levels of $\theta$ obtained when individual islands were treated independently $\left(\theta_{\mathrm{ST}}\right.$ for island groups $=0.3650$; upper $\mathrm{CI}=0.4666$, lower $\mathrm{CI}=0.2563$ ). Ordination analyses provide qualitative support for patterns produced in the UPGMA dendrogram. Plots of the first two principal coordinates reiterated the differentiation of northern and southern island groups, and further illustrated the relatively loose alliance of individuals from Frégate with representatives of the northern island group (Additional file 1).

\section{Phenotypic data \\ Univariate analyses}

Body width and head trait dimensions are strongly sexually dimorphic in $H$. rostratus (Fig. 5). Females have wider bodies than males regardless of island of origin. In general, females have smaller adjusted mean values for head length and width, and shorter IO (see Methods for description of morphological measurement abbreviations), IN, EN, ET, and TN distances. The notable exception is females from Curieuse, which have larger adjusted mean values for head length and width, and longer IO, EN, ET, and TN distances. This difference is reflected in the significant interaction between sex and island of origin for all but one trait (IN distance) for head morphology.

Numbers of folds, scales and vertebrae (PF, VF, SF, VERT, SR, and PFS) vary significantly only with island of origin (Fig. 5; Additional file 1), although a significant interaction for vertebrae suggests that variation in this character is also somewhat dependent upon the sex of the individual. There are no distinct patterns in the differences for number of folds, folds with scales, scale rows, or vertebrae among islands. 


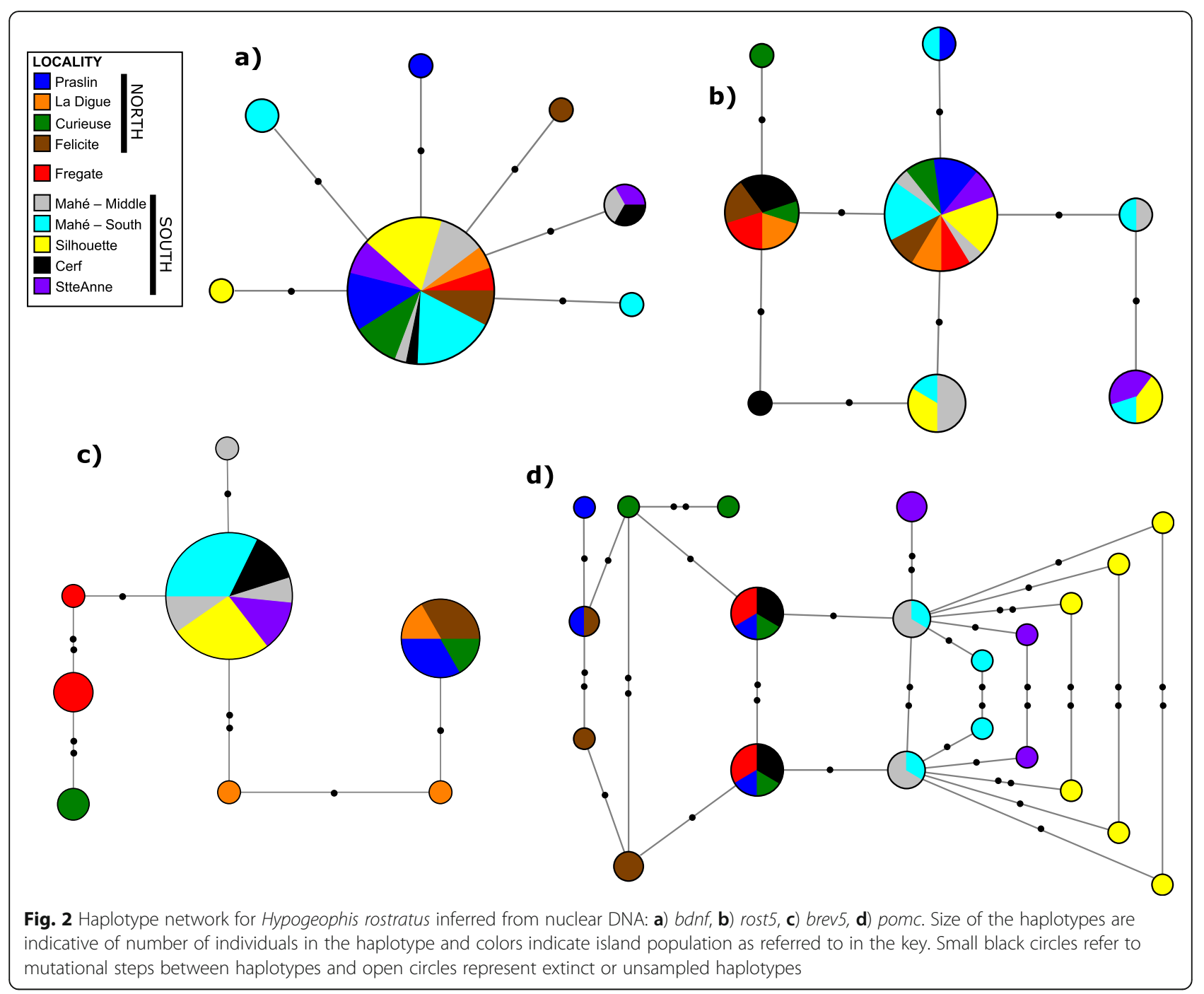

Table 2 Genetic diversity measures for Hypogeophis rostratus

\begin{tabular}{llllllll}
\hline \multirow{2}{*}{ Island } & Island & \multicolumn{7}{l}{} & & & \\
\cline { 2 - 7 } & Mahe & Silhouette & Ste. Anne & La Digue & Frégate & Praslin & Curieuse \\
\hline Mahe & $\mathbf{0 . 1 8 9 7}$ & 0.0262 & 0.0349 & 0.2724 & 0.1606 & 0.4350 & 0.3786 \\
Silhoutte & 0.00026 & $\mathbf{0 . 1 7 5 7}$ & 0.0514 & 0.2800 & 0.1814 & 0.4291 & 0.3749 \\
Ste. Anne & 0.00243 & 0.00188 & $\mathbf{0 . 1 6 5 2}$ & 0.2783 & 0.1857 & 0.4326 & 0.3590 \\
La Digue & 0.03237 & 0.03247 & 0.03333 & $\mathbf{0 . 0 9 6 3}$ & 0.1113 & 0.1916 & 0.1851 \\
Frégate & 0.03728 & 0.03704 & 0.03790 & 0.00495 & $\mathbf{0 . 1 1 8 1}$ & 0.4291 & 0.3749 \\
Praslin & 0.03728 & 0.03704 & 0.03790 & 0.00495 & 0.00571 & $\mathbf{0 . 0 4 1 7}$ & 0.0611 \\
Curieuse & 0.03776 & 0.03752 & 0.03838 & 0.00543 & 0.00048 & 0.00619 & $\mathbf{0 . 0 6 2 8}$ \\
\hline
\end{tabular}

Genetic diversity measures for Hypogeophis rostratus within and between islands. Values on the diagonal are within-island average dissimilarity based on AFLP markers for 274 individuals. Values above the diagonal are Nei's (1978) genetic distance (d) based on AFLPs, and values below the diagonal are the net number of substitutions per site $\left(D_{a}\right)$ between islands 


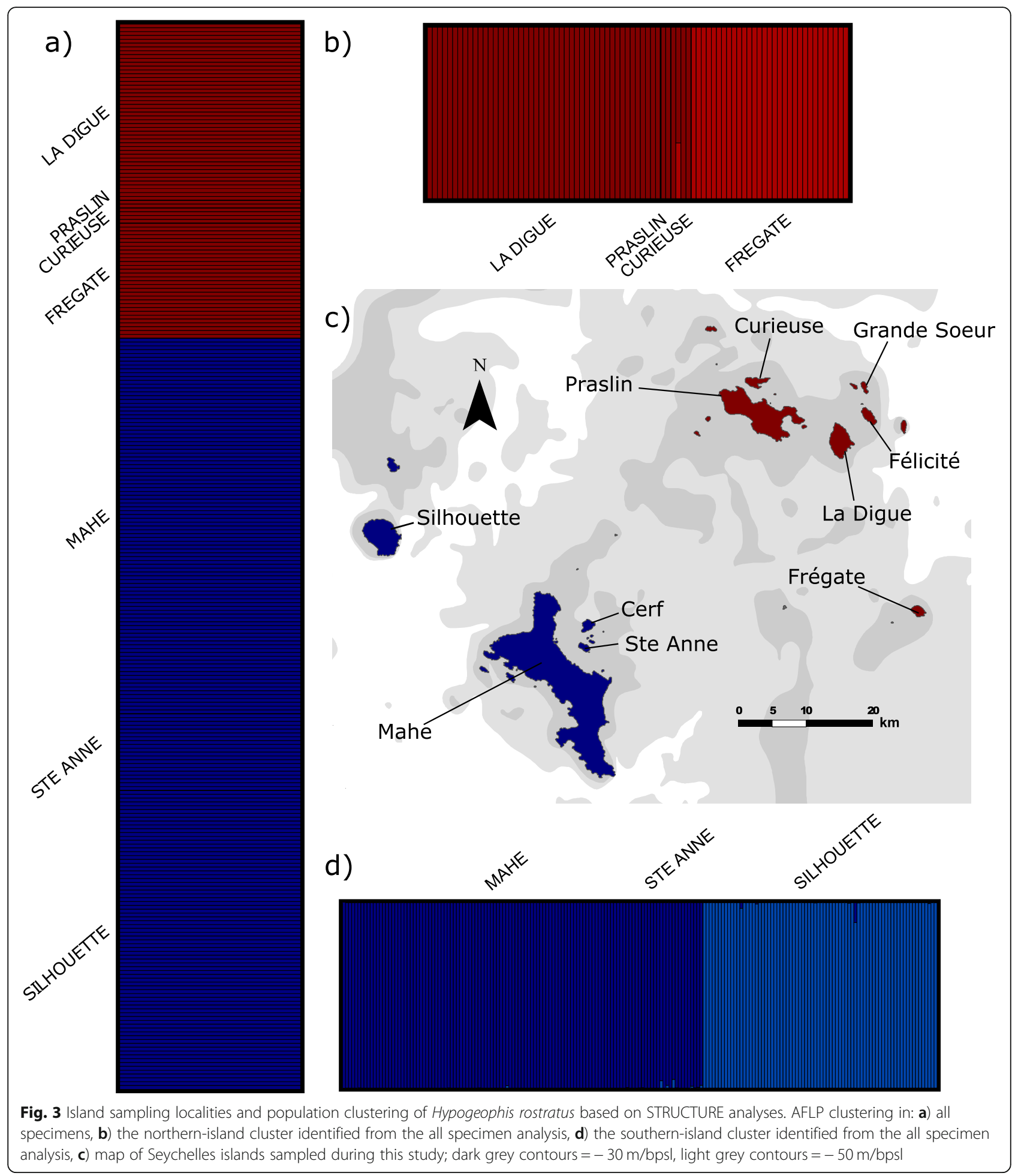

\section{Multivariate analyses}

The PCoA plots (Fig. 6) for both males and females show little overlap between southern and northern island samples, and much more overlap and scatter for samples from individual islands within each of these two main groups. In this multivariate analysis of morphological traits, the
Frégate samples overlap much more extensively with the southern island group samples than the northern island group. The PCA plots (Additional file 1) generally agree with the PCoA plots in terms of the similarity of samples from the different islands. For males, the first two principal components account for $92 \%$ of the variation in the 


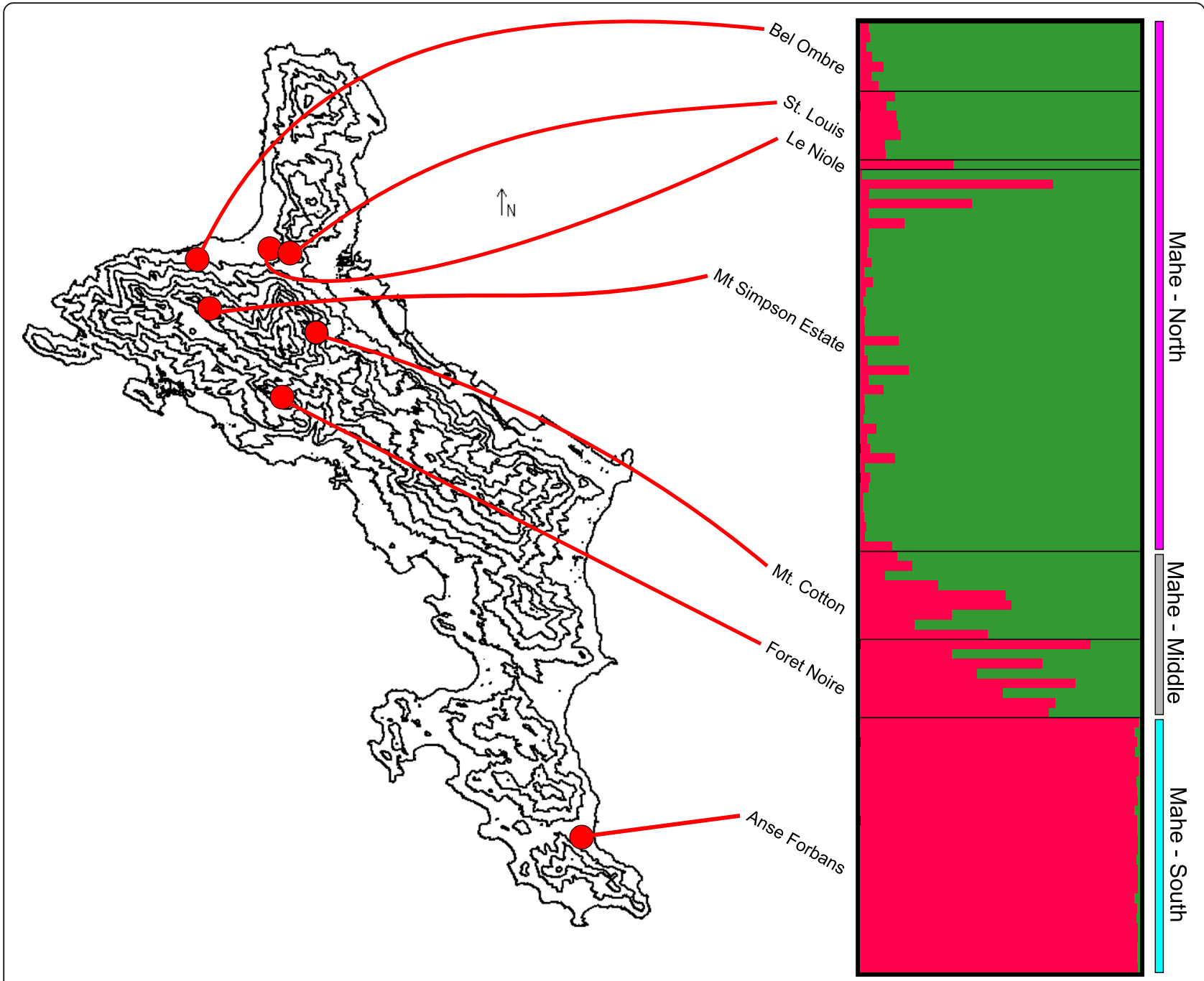

Fig. 4 Intra-Mahé AFLP clustering of Hypogeophis rostratus samples from STRUCTURE analyses. Contour lines on map are at $100 \mathrm{~m}$ elevational intervals. Referred populations to the northern, middle and southern groups are indicated to the right of the STRUCTURE plot

data, with the first principal component (PC1) explaining $86 \%$ of the total variance. Factor loadings for PC1 were high and positive for head length and width $(0.64$ and 0.47 , respectively) and moderately positive for other head traits (range: 0.11-0.35). Factor loadings for PC2 were high and positive for HW (0.74), moderately positive for IO (0.26) and BW (0.11), high and negative for HL ($0.61)$ and low and negative $(-0.02$ to -0.08$)$ for other head measures. For females, the first two principal components account for $89 \%$ of the variability in the data, with PC1 explaining $82 \%$ of the total. Similar to the pattern in males, factor loadings for PC1 were high and positive for head length (0.6) and width (0.53), and other head trait dimensions (range: 0.1-0.36). Factor loadings for PC2 were high and positive for HW (0.72), moderately positive for BW (0.2) and IO (0.24), and moderately negative for $\mathrm{HL}$, EN, and ET (-0.26--0.46).
UPGMA dendrograms based on Mahalanobis distances among islands for males and females have identical branching patterns and differ only in branch length (Fig. 6). This analysis recovers two groups of islands separating the northern and southern islands, supporting the findings from the mtDNA and AFLP analyses. However, a notable difference to the genetic data is the placement of the Frégate samples, which are joined by a long branch to the group of southern islands (rather than clustering with the northern islands).

\section{Phenotypic subdivision}

The mean level of island group (northern island + Frégate, and southern island groups) subdivision for all morphological characters was $0.18\left(\mathrm{P}_{\mathrm{ST}}\right)$ in both males and females. Levels of phenotypic subdivision were high for VERT and PF in both males and females (males: 0.46 
Paddock et al. BMC Evolutionary Biology

(2020) 20:110

Page 9 of 20

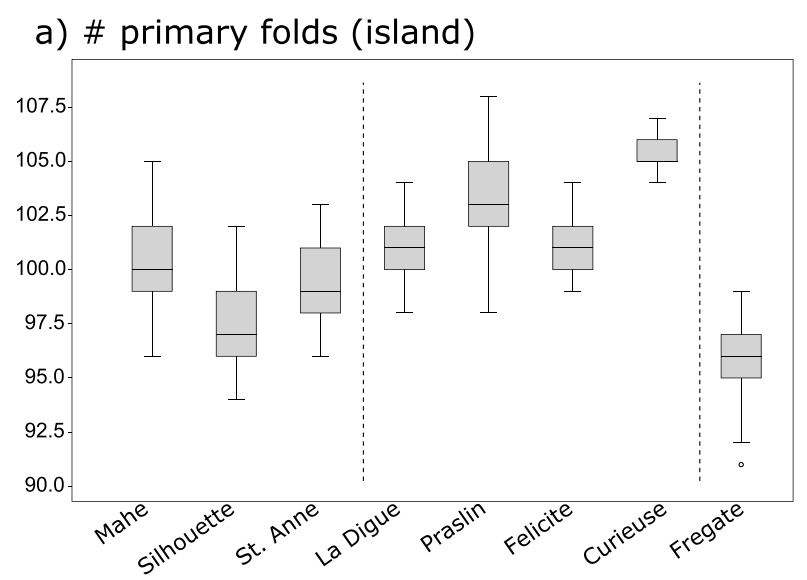

b) \# vertebrae (island)

c) \# secondary annular grooves (island)
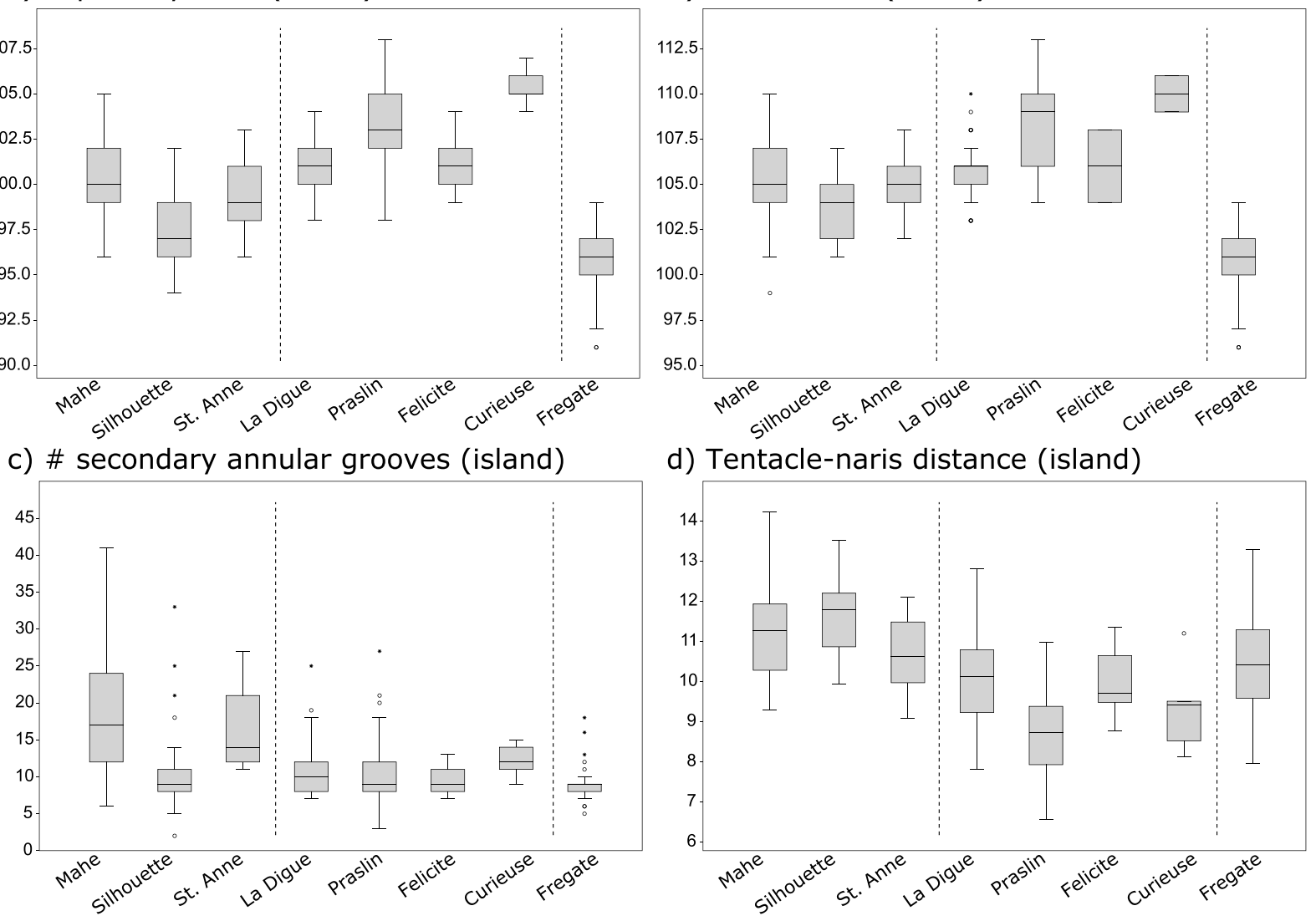

d) Tentacle-naris distance (island)

e) Head length (sex)

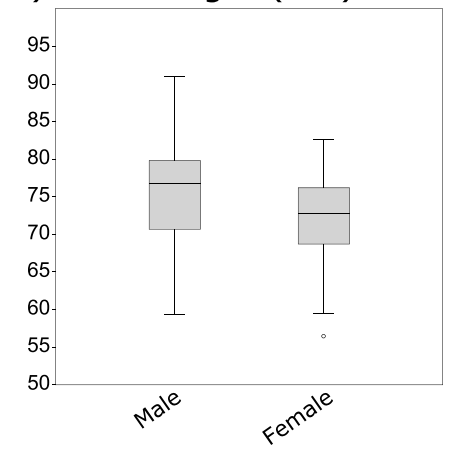

h) Eye-tentacle distance (sex)

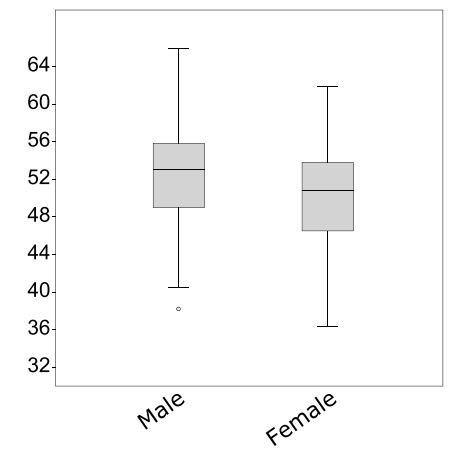

f) Head width (sex)

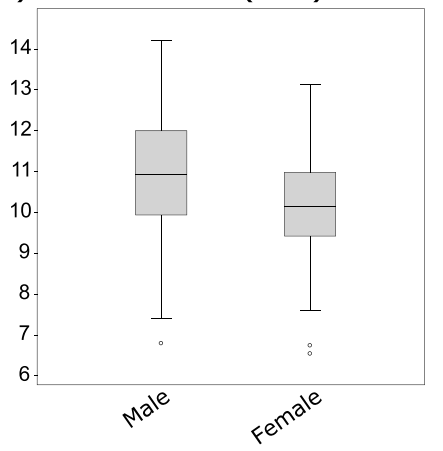

i) inter-narial distance (sex)

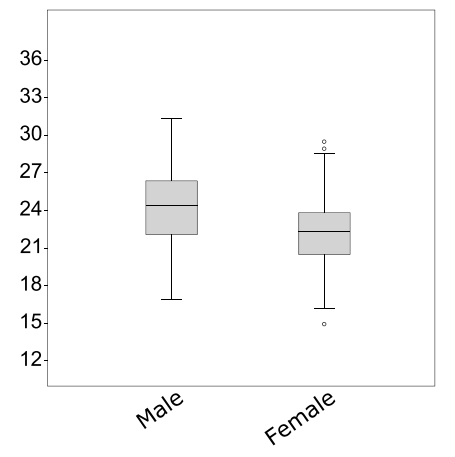

g) Tentacle-naris distance (sex)

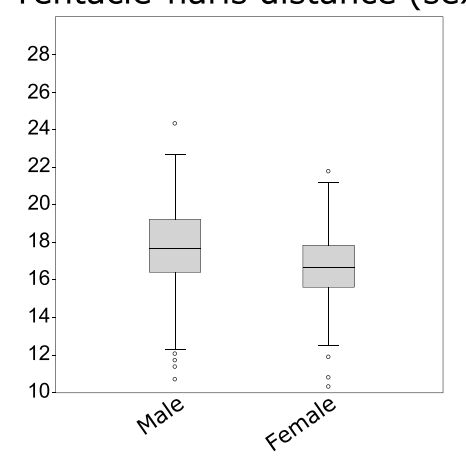

j) Eye-naris distance (sex)

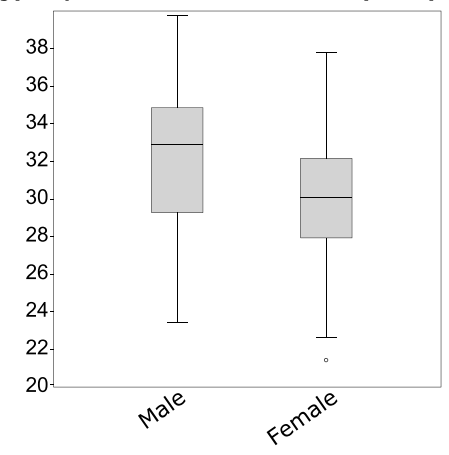

Fig. 5 (See legend on next page.) 
(See figure on previous page.)

Fig. 5 Boxplots of morphological data for Hypogeophis rostratus, depicting similarity among samples from different islands (a-d) and sex (e-j). Differences between islands in: a) number of primary folds, $\mathbf{b}$ ) number of vertebrae, c) number of secondary annular grooves, d) TN. Sex comparison: e) $\mathrm{HL}, \mathbf{f}) \mathrm{HW}, \mathbf{g}) \mathrm{TN}, \mathbf{h}) \mathrm{ET}, \mathbf{i}) \mathrm{IN}, \mathbf{j}) \mathrm{EN}$. The number of individuals used in boxplots were as follows: Mahé $n=51$ males \& 55 females, Silhouette $n=26$ males \& 15 females, Sainte Anne $n=8$ males \& 8 females, Frégate $n=18$ males \& 21 females, Praslin $n=23$ males \& 18 females, La Digue $n=30$ males \& 16 females, Curieuse $n=5$ males, Félicité $n=9$ males \& 11 females

and 0.47 , respectively; females: 0.52 and 0.48 , respectively). Values for all remaining traits for males and females were between 0.09 and 0.24 .

Although there is substantial evidence of sexual dimorphism in $H$. rostratus, as demonstrated by the ANCOVA analysis, there is no evidence that morphological variation among islands differs by sex. Mahalanobis distance between islands is highly correlated in males and females (Mantel test; $\mathrm{r}=0.9, p=0.001$ ) (Additional file 1 ). A linear regression of $\mathrm{P}_{\mathrm{ST}}$ for traits in females versus males shows a high correlation between the amount of island subdivision in the two sexes $(\mathrm{r}=0.98, p<0.001)$ (Additional file 1). The slope of the least-squared regression line is not significantly different from one (lower $\mathrm{CI}=$ 0.80 ; upper $\mathrm{CI}=1.02$ ) and the intercept not significantly different from zero (lower $\mathrm{CI}=-0.01$; upper $\mathrm{CI}=0.03$ ), indicating that male-female traits have evolved in a similar manner.

\section{Combined data set analyses}

Simple Mantel tests of distance matrix associations revealed significant correlations between all of the datasets apart from between mtDNA vs. female morphometric data and between male morphometric data vs. geographic distance (Table 3 ). These relationships are indicative of isolation-by-distance.

The partial Mantel test results indicate a significant association between genetic (mtDNA and AFLP) and geographic distance while controlling for morphology (male and female). There is a marginally significant association between AFLP and morphological (male and female) data while controlling for geography (Table 3).

The correlations between Nei's $d$ (AFLP) and $D_{a}$ (mtDNA) between islands was $r=0.81(p=0.24)$. The relationships between molecular genetic divergence at AFLP markers and Mahalanobis distance were significant for males ( $r=0.49, p=0.024$ ) and marginally significant for females $(r=0.43, p=0.052)$. The correlations between the mtDNA based $D_{a}$ and Mahalanobis distances for males and females were positive but not significant (males: $r=0.25, p=0.134$; females: $r=0.18, p=0.147$ ).

\section{Discussion}

Genetic and morphological data for Hypogeophis rostratus generally support the presence of northern island (Praslin, La Digue, Curieuse, Felicite) and southern island (Mahé, St. Anne, Silhouette, Cerf) lineages. Samples from the most easterly island, Frégate, are morphologically distinct and evidence for their affinities to either the northern or southern island group differs for morphology and genetics. The sequence data suggest that no gene flow has been occurring between the two main mtDNA lineages-northern + Frégate and the southern island populations-in the recent past but that the two lineages have a Pleistocene divergence. Geographic expansions and subdivisions would have been facilitated by cyclically oscillating sea levels during this time [32]. Taken together with the AFLP data, the sharing of alleles among samples from different islands, regardless of mtDNA lineage, in the nuclear sequence data is likely indicative of ancestral polymorphism and incomplete lineage sorting rather than recent dispersals between islands.

The spatial structuring of phenotypic and genetic variation within $H$. rostratus (especially the partitioning into northern- and southern-island groups) is broadly similar to that observed within Seychelles lizards [39, 44-46, 51, 52], frogs [40, 48] and crabs [47]. This spatial (and temporal) pattern is likely caused by rising sea levels sundering formerly widespread populations and/or IBD across Seychelles taxa. The extreme ecomorphological disparity among different taxa with divergent northern and southern island lineages, some of which should not be as osmotically challenged as caecilians (i.e. lizards), shows that geographic distance and marine barriers have played a major role in shaping the evolutionary history of the Seychelles biota.

That the molecular tree supports a northern + Frégate island group, whereas morphology does not, could be explained by local ecological adaptation acting on the morphology of $H$. rostratus on Frégate. The small size of Frégate (ca. $2 \mathrm{~km} \times 1 \mathrm{~km}$ ), and the relatively low genetic variation observed in $H$. rostratus there, could be explained by genetic drift, founder effects and/or by local adaptation generating selective sweeps e.g. [3-7]. Adaptation could be a plausible explanation for the incongruence given that Frégate differs from both the cooler, wetter southern islands and the drier, warmer (and palm dominated) northern islands. However, further interpretation is complicated by the typically human modified nature of most habitats across the granitic Seychelles, and a lack of precise data on the native vegetation of Frégate and of detailed climate records. Genetic drift, particularly as a result of founder effects, is common in island systems, especially when new populations are formed 


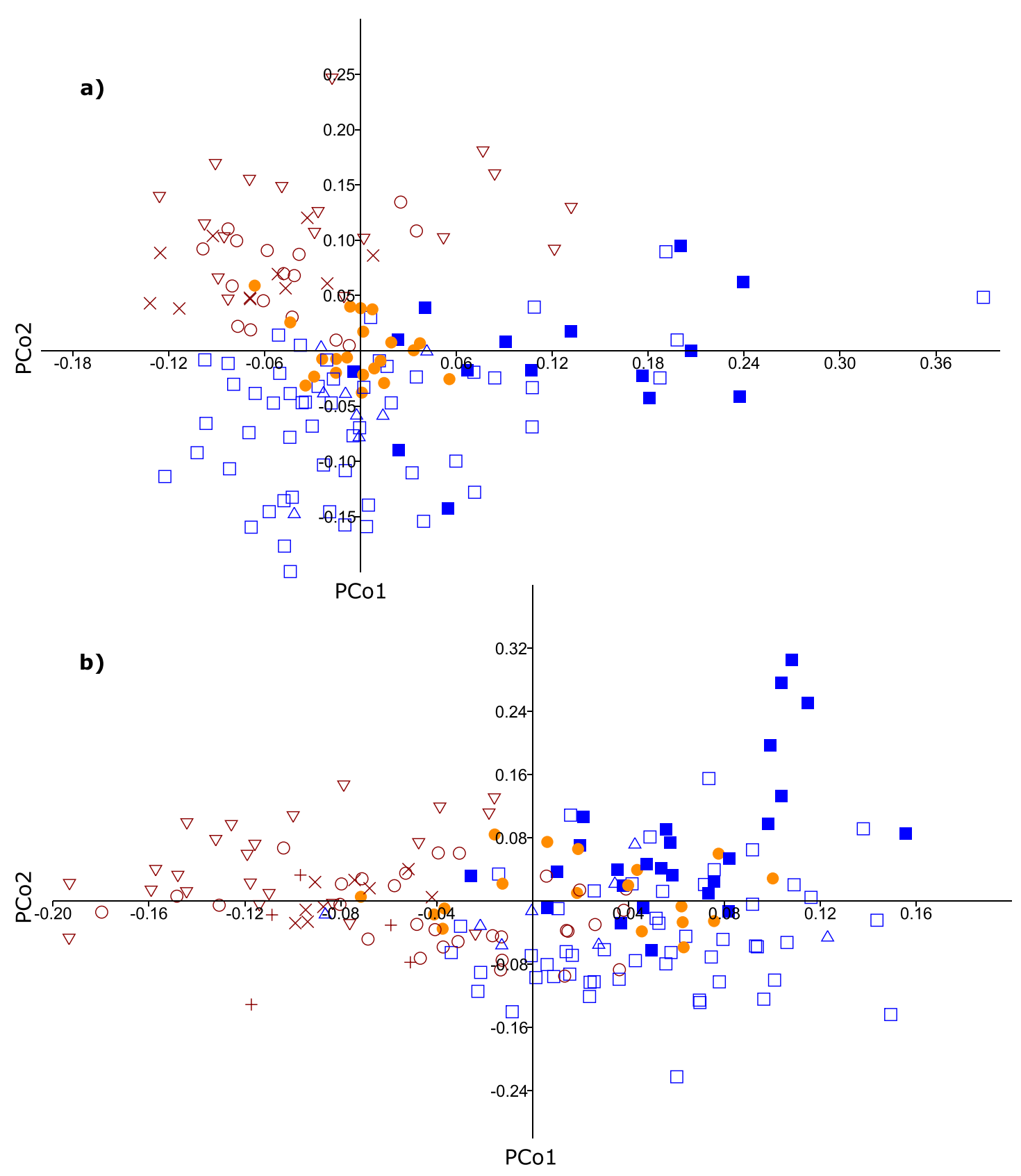

c)

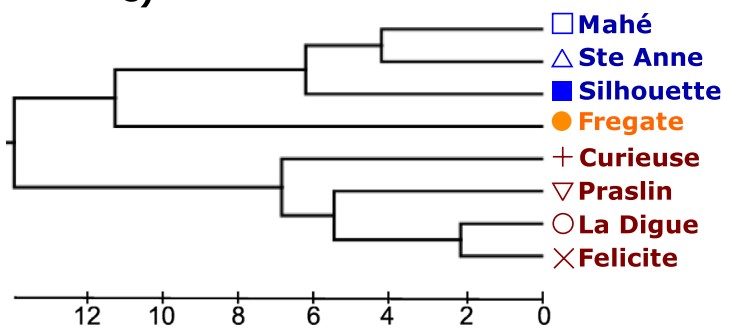

d)

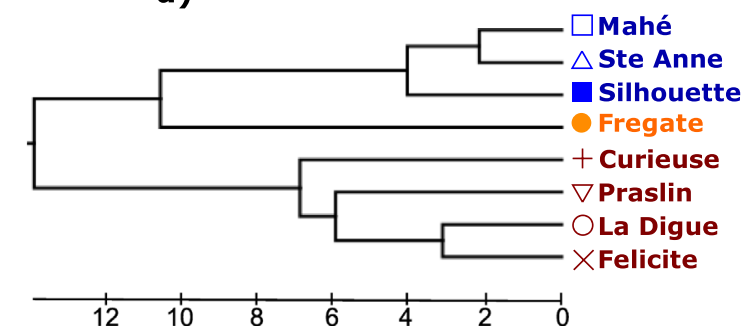

Fig. 6 Multivariate analyses of Hypogeophis rostratus morphological data: a) PCoA plot of females, b) PCoA plot of males. UPGMA dendrograms based on Malhanobis' D between all island pairs: c) males, $\mathbf{d}$ ) females. Colors and symbols used in the PCoA plots, match those used in the UPGMA dendrograms. The same individuals were used as in Fig. 5 
Table 3 Mantel and partial Mantel tests results for variation in Hypogeophis rostratus

\begin{tabular}{|c|c|c|c|c|}
\hline & \multicolumn{2}{|l|}{ mtDNA } & \multicolumn{2}{|l|}{ AFLP } \\
\hline & $R$ & $p$-value & $R$ & $p$-value \\
\hline \multicolumn{5}{|l|}{ Simple Mantel } \\
\hline Genetic x Geographical & 0.737 & 0.03 & 0.818 & $<0.01$ \\
\hline Genetic x Morphometric (१) & 0.356 & n.s. & 0.596 & 0.01 \\
\hline Genetic x Morphometric (ठ̋) & 0.561 & 0.01 & 0.534 & 0.02 \\
\hline Morphometric (Q) x Geographic & 0.463 & 0.03 & & \\
\hline Morphometric $(\widehat{o}) \times$ Geographic & 0.406 & n.s. & & \\
\hline \multicolumn{5}{|l|}{ Partial Mantel } \\
\hline Genetic x Geographic | Morphometric () & 0.691 & 0.04 & 0.761 & $<0.01$ \\
\hline Genetic x Geographic | Morphometric (ふ̋) & 0.673 & 0.02 & 0.778 & $<0.01$ \\
\hline Genetic x Morphometric (P) | Geographic & 0.024 & n.s. & 0.425 & 0.03 \\
\hline Genetic x Morphometric (ふ̋) | Geographic & 0.423 & n.s. & 0.384 & 0.02 \\
\hline Morphometric (q) x Geographic | Genetic & 0.319 & n.s. & -0.051 & n.s. \\
\hline Morphometric (ぶ) x Geographic | Genetic & -0.013 & n.s. & -0.063 & n.s. \\
\hline
\end{tabular}

n.s. indicates a non-significant result for $p$-values

either via colonization or isolation e.g. [83] and is a potential explanation of allelic fixation and reduced variation.

Association between the different datasets (Table 3) strongly supports the general patterns of genetic and morphological variation being explained by isolation-bydistance (IBD) rather than isolation-by-adaptation (IBA) within $H$. rostratus. This observation matches similar interpretations for Seychelles lizards [42-46], though formal tests have not been performed for these other taxa to address this. Some support exists for IBA in the $H$. rostratus AFLP dataset but application of a more stringent significance threshold $(P=0.001)$ has been recommended due to the high Type I errors in partial Mantel tests [84], which would deem the results obtained here non-significant. IBD and the marine barriers are almost certainly jointly responsible for the geographic patterns of variation observed, which are likely caused predominantly by vicariance rather than dispersal.

There is substantial, spatially structured intraspecific genetic variation within $H$. rostratus on the largest island of the Seychelles archipelago, Mahé. The genetic 'break' between a northernmost and more southerly group on Mahé lies among the high peaks (to a maximum of 905 m) within the Morne Seychellois National Park. We have encountered $H$. rostratus from sea level to $670 \mathrm{~m}$, and so it seems unlikely that the genetic subdivision was caused by a high-elevation barrier to gene flow (there is no obvious extant barrier), and this is somewhat supported by the observation that $H$. rostratus from directly south of Morne Seychellois (from Foret Noire and Mt. Coton) share alleles with individuals from localities to both the north and south. It seems more likely that the observed genetic subdivision is the result of IBD (possibly amplified by other environmental gradients) rather than purely or mostly by elevation. Due to a lack of sampling on Mahé it is not clear whether a continual or staggered gradient would be observed throughout the island. Although there are no records of $H$. rostratus from many parts of the island, this is likely due to a lack of targeted surveys rather than an absence of the species from these areas because the species seems to cope well with human induced habitat modification. Comparative data for intraspecific genetic structuring within Mahé is not available for other taxa but see [46].

Of the largest previous studies investigating molecular (and in some cases morphological) intraspecific geographic variation in caecilians, all but one [74] found substantial genetic diversity $[75,76]$. Both Stoelting et al. [75] and Wang et al. [76] suggested that genetic variation is associated with historic or present geographic barriers to gene flow rather than continuous, progressive IBD. In contrast, the marine barrier separating Seychelles islands coupled with IBD seem to be responsible for the spatially structured variation observed within $H$. rostratus.

We have uncovered substantial, spatially structured, intraspecific diversity associated with geographic barriers, based on the largest study of intraspecific genoand phenotypic variation of a caecilian species to date. The effects that demography and vicariance have on caecilian species had not previously been addressed in such detail. The findings here suggest that some caecilian species might be more capable of dispersing (e.g. H. rostratus between geographically close islands) than would have been expected, due to the predominantly fossorial nature of the Order. Our results provide a platform for future research into how populations of organisms with 
osmotically sensitive skin, distributed across ancient island archipelagos, are structured within their natural environments. The findings also substantially improve our understanding of biotic distribution, diversity and diversification across the Seychelles.

\section{Taxonomy}

Hypogeophis rostratus is morphologically distinct from congenerics and can be distinguished from other Hypogeophis, among many other features, by being much larger (all other species are $<120 \mathrm{~mm}$ in maximum length vs. $>400 \mathrm{~mm}$ ), in having many more vertebrae ( $>95$ vertebrae vs. < 80) and in having scales and secondary annular grooves only on the posteriormost part of the body [54, 55]. Analyses of $16 \mathrm{~s}$ rRNA (the only marker for which data are available for all Hypogeophis species and for both main lineages of $H$. rostratus) confirms the distinctiveness of $H$. rostratus from other Hypogeophis ( $p$-distance ca. $0.06 \%$ between northern and southern island lineages and a minimum of $8.5 \%$ between the genetically closest Hypogeophis (H. montanus). The morphology and genetic evidence (genetic distance within $H$. rostratus is two orders of magnitude lower than the minimum interspecific distance) provides strong support that the two main $H$. rostratus lineages are representative of infraspecific variation and not (taxonomically) associated with the three other currently recognized species of the genus.

Four subspecies have been formally described for $H$. rostratus: H. r. rostratus Parker, 1958 [60], H. $r$. guentheri (Boulenger, 1882) [85], H. r. praslini Parker, 1958 [60] and H. r. lionneti Taylor, 1969 [62]. Hypogeophis $R$. rostratus and $H$. r. praslini were described from types from the southwestern island of Mahé and northern island of Praslin, respectively. The holotype of $H$. $r$. guentheri was reported originally to be from Zanzibar (where no caecilians are known to occur), but Parker [60] suggested that it was likely instead to be from the Seychelles island of Frégate based on its low number of vertebrae. The holotype of $H$. r. lionneti is from an unspecified locality within the Seychelles. These subspecies have been ignored in the scientific literature since Taylor [61], including in conservation assessments [86].

Our data support the recognition of at least two distinct evolutionary significant units for $H$. rostratus. These conform to a northern lineage, potentially referable to $H$. r. praslini and a southern lineage potentially referable to $H$. r. rostratus. However, the incongruence of the affinities of specimens from Frégate with the northern (genetic) or southern (morphology) populations would prevent compelling assignment of Frégate $H$. rostratus to either of these two subspecies. The lack of reliable locality data for the types of $H$. r. lionneti and $H$. $r$. guentheri and the absence of discrete diagnostic characters for the island populations further complicates the situation. We recommend that no subspecies should currently be recognized for $H$. rostratus, pending a broader genomic sampling that allows us to better assess the levels of differentiation versus gene-flow across these islands. However, there is an argument for treating at least the northern island, southern island and Frégate populations as distinct conservation management units in order to preserve diversity. If marine barriers are maintained long into the future then the subunits identified here could be considered incipient species.

\section{Conclusions}

Genetic and morphological data support a geographically structured northern island and southern island clade within the Seychelles caecilian Hypogeophis rostratus. The eastern island of Frégate is nested within the northern island clade in all molecular analyses, but conversely occupies a more intermediate position between the two clades based on the morphological data. It is likely that a combination of IBD and vicariance has shaped the geographic structure observed within the species, with a primary split between the populations estimated at ca. 1.2 MA [95\% HPD: 0.45-1.94 MA], with no migration occurring between them, despite multiple low stands in sea level. The data support the recognition of a single but variable species.

\section{Methods \\ Data collection \\ Sampling and DNA isolation}

Typically, caecilians are considered difficult to find due to their mostly burrowing nature [87], such that substantial, dedicated fieldwork can be required to collect suitable numbers of samples for phylogeographic projects. This difficulty in sampling is perhaps one reason that very few studies of caecilian molecular ecology have been undertaken [74-76]. Hypogeophis rostratus were collected on nine granitic islands in the Republic of the Seychelles between 1981 and 1991, and between 2013 and 2015: Mahé, Sainte Anne, Cerf, Silhouette, Frégate, La Digue, Praslin, Curieuse, and Félicité (Fig. 3). Our sampling covers the known distribution of the species [56] with the exception of the small island of Grande Soeur. We included a total of 782 individuals in the various components of this study (Additional file 2). The specimens collected between 1984 and 1991 for molecular analyses (mt- \& nuDNA sequences and AFLPs) were either returned live to the lab, subsequently euthanized, and liver and muscle tissues snap frozen and stored at $80 \mathrm{C}$ at University of Michigan Museum of Zoology; or they were collected in the field and snap frozen. Additional tissue samples were collected between 2013 and 2015 for molecular analyses (mt- and nuDNA sequences) and were processed in the field or were non- 
lethally sampled (buccal swabs and/or annular pocket biopsies, following [88]) and stored in 100\% EtOH. Specimens used for morphological analyses (collected between 1984 and 1991) were fixed in 10\% buffered formalin and stored in 65-70\% EtOH. Samples utilized in this study are represented by vouchers accessioned to the permanent collections of the Natural History $\mathrm{Mu}-$ seum, London (BMNH, issued with SM field codes) and the University of Michigan Museum of Zoology (UMMZ) (Additional file 2). Genomic DNA from 312 individuals of Hypogeophis rostratus from nine islands was obtained from tissue by a standard [89] proteinase $K$ digestion with either a phenol/chloroform/isoamyl alcohol extraction or a Qiagen DNeasy Blood and Tissue kit [see 88 for non-lethal DNA extraction protocols].

\section{DNA amplification for sanger sequencing}

The polymerase chain reaction (PCR) was used to amplify a portion of the mtDNA cytochrome $b(c y t b)$ gene from 100 individuals sampled from nine islands (Additional file 1) and four nuclear loci for 26 individuals from seven islands; samples for sequencing were semirandomly selected in order to obtain geographic coverage. The nuclear loci consisted of portions of two protein coding genes (pro-opiomelanocortin (pomc) and brain-derived neurotrophic factor $(b d n f)$ ) and two anonymous nuclear markers (brev5 and rost5) [79]. See Additional file 1 for primer, DNA amplification, sequencing and sequence editing details.

\section{Amplified fragment length polymorphism (AFLP) data generation}

AFLP data were used to assess nuclear genetic variation among sampled populations of $H$. rostratus. AFLP marker profiles were generated for a total of 274 individuals from seven islands (all of these seven islands were among those sampled in the mitochondrial and nuclear DNA sequence datasets: Additional file 2), collected between 1984 and 1991, using the protocol described by Vos et al. [90] with modifications described in Mock and Miller [91]. In the second selective amplification step, the following four primer combinations were used to generate multilocus DNA fingerprints: EcoACG/ MseAGA, EcoACG/MseACT, EcoAGG/MseATC, EcoAGG/MseAGA. After the second selective amplification, PCR products were run on an ABI 3100 automated DNA sequencer (Applied Biosystems, Inc.) using a Rox400 internal size standard. Repeatability was checked by duplicating ca. $15 \%$ of samples. Following sequencer runs, the presence or absence of individual AFLP marker phenotypes were visualized and scored using Genographer [92]. Markers were scored if they were polymorphic (95\% criterion) and could be scored unambiguously across the dataset. Scoring was performed without reference to sample or population identity. The final AFLP dataset included data from 49 polymorphic loci.

\section{Phenotypic traits}

Morphological data were generated for 506 individuals of $H$. rostratus from eight islands (including all islands that were sampled for mitochondrial and nuclear DNA sequence data: see Additional file 1). Only individuals collected between 1984 and 1991, that were in a good preservation state, were examined for morphology. The sex of 461 of the specimens was determined by direct examination of gonads (females $=231$, males $=230$ ). We examined 5 males and 4 females from Curieuse, 9 males and 11 females from Félicité, 17 males and 21 females from Frégate, 30 males and 15 females from La Digue, 98 males and 115 females from Mahé, 37 males and 39 females from Praslin, 2 males and 2 females from Sainte Anne, and 26 males and 17 females from Silhouette. A ruler was used to record total length to the nearest 1.0 $\mathrm{mm}$. Dial calipers were used for all other measurements. Body width was measured to the nearest $1.0 \mathrm{~mm}$, all remaining measurements to the nearest $0.1 \mathrm{~mm}$. The morphological measures recorded were: total length (TL), body width at midbody (BW), head length measured dorsally from tip of snout to first groove of first collar (HL), head width at level of corner of mouth (HW), inter-ocular distance between medial borders of eyes (IO), inter-narial distance between medial borders of nares (IN), eye-naris distance from anterior margin of eye to posterior margin of naris (EN), eye-tentacle distance from anterior corner of eye to midpoint of tentacular aperture (ET), tentacle-naris distance from midpoint of tentacular aperture to posterior margin of naris (TN), number of primary annular folds (grooves) after second collar (PF), number of primary annular folds interrupted by the vent (VF), number of primary annuli bearing partial or complete secondary annular folds (SF), number of secondary folds that completely encircle the body (CSF), total number of vertebrae counted from x-ray plates (VERT), number of overlapping rows of scales in a posterior primary fold counted in the dorsal region (SR), and number of primary folds containing scales (PWS) determined using the method described by Wilkinson et al. [93].

\section{Data analyses \\ Mitochondrial and nuclear DNA sequence analyses}

We inferred relationships among individuals by constructing haplotype networks and by inferring phylogenetic trees. Individual alleles for diploid nuclear sequences were reconstructed using PHASE v.2.1.1 [94]. Input files for PHASE were produced using seqPHASE [95]. PHASE was executed three times for each locus, at a random starting seed, for 1000 iterations, a 10 thinning 
interval, and 100 burn-in. Each run was examined for mean frequency concordance, and the run that was most similar to zero selected for further analysis. Sites with heterozygous probabilities of $\geq 0.7$ were considered to be correctly called by PHASE, others being coded as IUPAC ambiguities. Haplotype networks for $c y t b$ and nuclear sequence data were constructed using the median-joining algorithm [96] as implemented in the software NETWORK v.4.611 (fluxus-engineering.com). Uncorrected pairwise $(p-)$ molecular genetic distances and Tajima D values were estimated using MEGA X [97].

Phylogenetic trees were inferred for $c y t b$ using Bayesian inference (BI) methods. PartitionFinder v.2.1.1 [77] was used to identify the best-fitting partitioning strategy and models of sequence evolution. MrBayes v.3.2.2 [78] was used to infer the BI tree for $c y t b$, sampling every 10 , 000 generations over $10^{6}$ generations with one cold and three heated chains. Tracer v.1.7 [98] was used to check that chain convergence and good mixing occurred for all parameters and that all effective sample size (ESS) values were $>200$. Convergence was also investigated by assessing that the potential scale reduction factor (PSRF) was close to 1.0 for all parameters, that the average standard deviation of split frequencies was below 0.01 and that log probability was within a relatively stable range and not still increasing. The first 10\% of trees were discarded as burn-in. Cytb sequence data for a congeneric endemic Seychelles caecilian, $H$. brevis, were obtained from GenBank (HQ444110), and used as a closely related outgroup [38] to root phylogenetic trees. BI analyses were performed on the CIPRES Science Gateway v.3.1 [99].

Based on results from the initial molecular analyses, the Isolation-with-Migration (IM) model [100] as implemented in IMa2 [80, 101] was used to estimate population sizes, migration and time since divergence between the two major $H$. rostratus clades found ((Praslin, La Digue, Felicite, Curieuse, Frégate) and (Mahé, Silhouette, Cerf, St Anne)). The null hypothesis is that, since divergence, there has been no gene flow between the two (northern and southern island-group) lineages because of a saltwater barrier separating the two groups [28-32]. Initially, the mitochondrial cytb gene was used in the analyses (as its mutation rate would allow us the estimate of the parameters in meaningful demographic units) but after multiple independent runs, double peaks were observed in several parameters, which were likely a consequence of reciprocal monophyly between the two groups for $c y t b$ data. Final IMa analyses therefore were carried out with only the nuclear data. No molecular rate was provided for the nuclear data because of a lack of comparative evolutionary rates for these markers. The IS model was used for the nuclear loci. Posterior density curves were inspected for clear peak estimates and appropriate prior distributions boundaries. Priors were defined based on summary statistics and adjusted following initial runs. The final analysis was run five times with different starting seeds and checked for consistency between runs.

Time estimates for the split between the northern- vs southern-island lineages were made using "BEAST in BEAST2, defining each clade as a "species" [102] for all of the sequence data (mt- and nuDNA). We estimated divergence dates based on an evolutionary rate of approximately $1 \%$ sequence divergence per million years with a lognormal distribution and a standard deviation of 0.0027 for $c y t b$, following other studies of amphibians and reptiles $[45,103]$. Nuclear rates were estimated relative to $c y t b$. PartitionFinder v.2.1.1 [77] was again used to identify the best-fitting models of sequence evolution based, this time on each locus. Some of these were later replaced by their immediate less complex most similar model, when they failed to converge. The Yule Model prior was used as the tree-prior because we had no evidence of extinction in the population, and because choice of prior is unlikely to impact estimated divergence dates significantly [104]. As a test of time estimate robustness we also ran analyses using the Birth Death Model and the Coalescent (constant population size) priors. A log normal relaxed clock was used as the clock-prior for the $c y t b$ partition, and strict clock priors were used for the nuclear partitions (according to the coefficient of variation obtained during preliminary runs, a strict clock was considered appropriate to use). Analyses were run for $10^{6}$ generations, with sampling every 10,000 generations. Tracer was used to investigate that good mixing was occurring between all parameters and that ESS values were $>200$ as per previous analyses.

\section{AFLP analyses}

Two different approaches were used to quantify withinisland AFLP diversity. First, the program TFPGA [105] was used to calculate Nei's [81] unbiased heterozygosity. Allele frequencies were calculated from the dominant AFLP marker data using the allele frequency estimator of Lynch and Milligan [106]. Second, the program MANTEL-STRUCT [107] was used to obtain average pairwise band sharing coefficients between individuals within islands. This procedure calculates the average proportion of shared AFLP marker phenotypes among individuals.

Genetic structuring among islands and island groups was characterized using Wier and Cockerham's [108] estimate $\left(\theta_{\mathrm{ST}}\right)$ of Wright's $\mathrm{F}_{\mathrm{ST}}$ in Arlequin v.3.5 [109]. Ninety-five percent confidence limits of $\theta_{\mathrm{ST}}$ were obtained via bootstrapping over loci. Given that other analyses of our genetic data indicated the presence of two distinct island groups (see Results), we also estimated $\theta_{\mathrm{ST}}$ and its associated confidence limits for a posteriori 
grouping of islands. To further refine our inferences about patterns of genetic structure among islands, we used TFPGA to generate a UPGMA dendrogram based on pairwise Nei's [81] unbiased genetic distances. Support for resulting dendrogram clusters was quantified using a bootstrap procedure over loci (sensu Felsenstein 1985 [110]). To further characterize patterns of genetic differentiation, we used the program NTSYSpc (Exeter Software, Inc.) to perform a principal coordinates ordination to visualize patterns of (dis) similarity among all individuals included in AFLP analyses.

To identify the number of discrete populations $(K)$ that occur within the sampled $H$. rostratus we used a Bayesian clustering algorithm implemented in STRUCT URE v.2.3.4 [82]. To assess additional possible substructure, subsets of the data that formed distinct clusters in initial analyses were also subject to the same analyses (southern island group; northern island group; Mahé). Each individual analysis comprised four replicates of 100,000 steps with a 10,000 step burn-in. Given our assumption that individuals from the different islands have not been in contact, the no-admixture model with correlated allele frequencies was used [111]; tested $K$ values were specified based on the number of islands for which data were generated for (i.e. $K 1-K 7$ for the full dataset) in each analysis. An analysis of $H$. rostratus genetic variation within the largest, highest and geographically most complex Seychelles island of Mahé, which has the most sampled populations (seven) and specimens $(n=97)$, was carried out using the admixture model to investigate intra-island population structure. To infer the most likely $K$ for each dataset STRUCTURE HARVESTER [112] was used to determine $\Delta K$ [113]. The most likely $K$ value was then subjected to independent runs on STRUCTURE of $1 \times 10^{6}$ with a burn-in of 100,000 steps. Final summary figures of STRUCTURE results were created using distruct v.1.1 [114].

\section{Phenotypic data analyses}

Nussbaum \& Pfrender [115] presented evidence of sexual size dimorphism (SSD) in Frégate H. rostratus. We tested for SSD across all sampled islands using a twofactor analysis of covariance (ANCOVA) with TL as the covariate implemented using PROC GLM [116]. Using ANCOVA, trait means were adjusted for TL and tested for effects of sex, island of origin, and their interaction. Results from this analysis suggested strong dimorphism between males and females for body width and head dimension traits. Subsequent phenotypic multivariate analyses and estimation of levels of population subdivision for phenotypic traits were conducted separately for each sex.

Multivariate analyses for measures and counts of 16 phenotypic traits in 170 males and 146 females were conducted separately for each sex to determine patterns of morphological variation among islands. Principal components analysis (PCA) of metric characters (transformed relative to TL using the allometric vs. standard method [117]) and principal coordinates analysis (PCoA) of metric + meristic variables was implemented using PAST3 [118]. In addition, we estimated Mahalanobis distance matrices using PROC CANDISC (SAS 2003) to generate a matrix of pairwise island phenotypic distances. This matrix was used to construct UPGMA dendrograms of among island morphological variation for each sex using MEGA v.3.1 [119].

To examine patterns of phenotypic divergence on a trait-by-trait basis we obtained restricted Maximum Likelihood (ML) estimates of the variance components explained by island of origin $\left(\mathrm{V}_{\mathrm{i}}\right)$ and error $\left(\mathrm{V}_{\mathrm{e}}\right)$ for each trait using PROC VARCOMP [116]. Island and error variance estimates are analogous to estimates of the within and among island components of variance, respectively. These estimates were then used to calculate the level of population subdivision for phenotypic characters, $P_{S T}$, using the formula $V_{i} /\left(V_{i}+2\left(V_{e}\right)\right)$. This measure is analogous to the standard measure of quantitative trait subdivision $\mathrm{Q}_{\mathrm{ST}}[120,121]$. However, because our measurements were not taken from individuals reared in a common environment we cannot partition genetic from environmental effects, and thus $\mathrm{P}_{\mathrm{ST}}$ includes both genetic and environmental sources of variance. We used a nested design, with islands nested within groups (southern, and northern + Frégate island groups) to estimate the levels of subdivision at the level of island group. Because the univariate ANCOVA demonstrated significant sexual dimorphism we examined the correlation between males and females in population subdivision across all phenotypic traits using a least-squared regression of $\mathrm{P}_{\mathrm{ST}}$ values.

\section{Combined data analysis}

To assess factors influencing evolution within $H$. rostratus, simple and partial Mantel tests [122, 123] were employed to investigate isolation-by-distance (IBD) and isolation-by-adaptation (IBA), respectively. Morphometric (male and female), molecular (AFLP and mtDNA) and geographic distance data were used in IBD and IBA comparisons to investigate correlations among datasets. The vegan package [124] as implemented in R v. 3.2.3 [125] was used for all tests. Analyses were completed using the Pearson method with 999 permutations. For direct comparisons, only islands that had data available across all sampled datasets were used in tests, leaving a total of seven islands: Curieuse, Frégate, La Digue, Mahé, Praslin, Ste. Anne, Silhouette.

To produce distance matrices for the Mantel tests, appropriate analyses for each dataset were completed. For 
the morphometric data, Gower similarity coefficients for males and females were used and generated by PAST v.3.05 [118]. For AFLPs, $\Phi_{\mathrm{PT}}$ were generated using 999 permutations with the Microsoft EXCEL add-in GenA1Ex v.6.502 [126, 127]. For mtDNA data the Kimura two-parameter (K2P) model [128] was used to generate K2P distances in MEGA X [97] with partial deletion. The Geographic Distance Matrix Generator v.1.2.3 (Ersts; http://biodiversityinformatics.amnh.org/open source/gdmg/) was used to generate a pairwise distance matrix for each geographic sampling locality. The probability of the observed correlation was estimated by comparison with a distribution of correlation coefficients generated with 1000 random permutations of matrix elements.

\section{Supplementary information}

Supplementary information accompanies this paper at https://doi.org/10. 1186/s12862-020-01673-w.

Additional file 1. Fig. S1. a) UPGMA dendrogram of AFLP data. Support values are represented on the branches, where applicable. b) PCA plot of AFLP data for PCs 1 and 2. Fig. S2. a-e) correlation plots between datasets; f) Morphological trait subdivision ( $P_{S T}$ ) among islands. The average level of subdivision among islands for AFLP markers $\left(\theta_{s t}\right)$ is denoted by the solid line with the upper and lower confidence limits shown as dotted lines. See text for an explanation of the trait abbreviations and methodology; g-h) male vs. female correlation plots. Fig. S3. Fig. S3. PCA plots for: a) females, b) males. Colors and symbols are the same as those used in Fig. 6. Table S1. Primers used for PCR and Sanger sequencing. Table S2. Morphological patterns of variation between sexes and among islands. Least-squared adjusted means (one SE) and significance values for main effects of sex, island and sex-by-island interaction based on analysis of covariance (ANCOVA) with total length as the covariate using Type III SSR. Table S3. Mahalanobis' D between islands based on multivariate analysis of 16 morphological characters. See text for an explanation of the analysis. Males (Upper triangle) Females (Lower triangle)

Additional file 2. List of specimens used in this study and associated GenBank accession numbers for sequence data.

Additional file 3. Results of the final five independent IMa runs.

\section{Abbreviations}

MA: Millions of years ago; mtDNA: Mitochondrial DNA; nuDNA: Nuclear DNA; AFLP: Amplified Fragment Length Polymorphism; PCR: Polymerase chain reaction; cytb: Cytochrome $b$ (gene); bdnf: brain-derived neurotrophic factor (gene); pomc: Pro-opiomelanocortin (gene)

\section{Acknowledgements}

We thank K. Reed, J. Orwin and R. Wilcox for assistance in the laboratory. G. Schneider provided access to museum specimens and tissues. L. Chong Sheng, M. Nicoll, J. Watson, S. Warman, C. Raxworthy, F. Jeanne, A. Niole, G. Raharimanana, C. Morel, R. Bristol and J. Labisko assisted in the collection of material in the field. Seychelles Bureau of Standards for providing required field collection permits; and Seychelles National Park Authority for supporting STM with a gainful occupancy permit. We thank all project partners for support throughout the project and the Seychelles Ministry of Environment for issuing permits for research and export. We also thank $C$. Pinho for providing advice on IMa analyses, and A. Kupfer and O. Hawlitschek for helpful peer reviews.

\section{Authors' contributions}

STM and MEP drafted the manuscript with substantial contributions from DJG and JJD. All authors contributed to the writing of the final manuscript.
RAN and MEP designed the project. STM, RAN, DJG, JJD and MW collected samples in the field. STM, LL, MM, DLF, SR and MEP generated data and conducted analyses. All authors have read and approved the manuscript.

\section{Funding}

Funding for this research was provided by two grants from the National Science Foundation (BSR 88-17453, BSR 90-24505) [funding for fieldwork and lab work], two grants from the National Geographic Society (Grants 1977: 1633, 1743) [funding for fieldwork], three grants from the University of Michigan Office of the Vice President for Research, and a Research Partnership Award from the University of Michigan to RAN [morphology work]; a joint NHM-UCL IMPACT studentship [to fund STM's PhD, lab work and fieldwork], Mohamed Bin Zayed Species Conservation Fund [funding for fieldwork] and Systematics Research Fund [funding for fieldwork] to STM; an Institutional Development Award (IDeA) from the National Institute of General Medical Sciences of the National Institutes of Health under Grant \#P20GM103408 to LL [funding for lab work]; a NERC/BBSRC SynTax grant [funding for fieldwork and collaboration], and Darwin Initiative (grant 19002) [funding for fieldwork, lab work and capacity building] with partners Bristol University, Islands Conservation Society, Seychelles Islands Foundation, Seychelles Ministry of Environment, Seychelles National Parks Authority, Seychelles Natural History Museum, University of Kent, Zoological Society of London to MW, DJG, JJD. The funding bodies played no role in the design of the study and collection, analysis, and interpretation of data and in writing the manuscript.

\section{Availability of data and materials}

All sequence data generated in this study is available on GenBank (cytb = MT569151 - MT569250, bdnf = MT569251 - MT569274, pomc = MT569275 MT569293, brev5 = MT569294 - MT569319, rost5 = MT569320 - MT569344: see Additional File 2 for full details). Sequence alignments, AFLP data, morphological data, XML files and R scripts are deposited on the NHM Data Portal (https://doi.org/10.5519/0002481).

\section{Ethics approval and consent to participate}

No ethical approval was required for this work because no experimentation was carried out, although, the University of Michigan Animal Care Unit (UCUCA) approved all methods. The Seychelles Bureau of Standards approved field collection permits.

\section{Consent for publication}

Not applicable.

\section{Competing interests}

The authors declare that they have no competing interests.

\section{Author details}

${ }^{1}$ Present address: Faculty of Science and Engineering, University of Wolverhampton, Wolverhampton WV1 1LY, UK. ²Department of Life Sciences, The Natural History Museum, London SW7 5BD, UK. ${ }^{3}$ Department of Genetics, Evolution and Environment, University College London, WC1E 6BT, London, UK. ${ }^{4}$ Island Biodiversity and Conservation Centre, University of Seychelles, Mahé, Seychelles. ${ }^{5}$ Research Museums Center, University of Michigan, Ann Arbor, MI 48108, USA. ${ }^{6}$ Division of Natural Sciences and Mathematics, Lewis-Clark State College, Lewiston, ID 83501, USA.

${ }^{7}$ Department of Biology, Utah State University, Logan, UT 84322, USA. ${ }^{8}$ McPherson Eye Research Institute, University of Wisconsin, Madison, WI 53705, USA. ${ }^{9}$ Biomedical Research Center (CINBIO), University of Vigo, Vigo, Spain. ${ }^{10} \mathrm{G}$ alicia Sur Health Research Institute, Vigo, Spain. ${ }^{11}$ Department of Biological Sciences, University of Notre Dame, Notre Dame, Indiana 46556, USA.

Received: 7 April 2020 Accepted: 12 August 2020

Published online: 26 August 2020

\section{References}

1. Darwin C. The origin of species. London: John Murray; 1859.

2. Whittaker R, Fernandez-Palacios J. Island biogeography. 2nd edition. In: Oxford University press; 2007.

3. Wright S. Statistical genetics and evolution. Bull Am Math Soc. 1942:48:22347. https://doi.org/10.1090/S0002-9904-1942-07641-5. 
4. Hartl DL, Clark AG. Principles of population genetics. Sunderland: Sinauer Associates; 1997.

5. Kolbe JJ, Leal M, Schoener TW, Spiller DA, Losos JB. Founder effects persist despite adaptive differentiation: a field experiment with lizards. Science. 2012;335:1086-9. https://doi.org/10.1126/science.1209566.

6. O'Neill EM, Beard KH, Pfrender ME. Cast adrift on an island: introduced populations experience an altered balance between selection and drift. Biol Lett. 2012;8:890-3. https://doi.org/10.1098/rsbl.2012.0312.

7. Spurgin LG, Illera JC, Jorgensen TH, Dawson DA, Richardson DS. Genetic and phenotypic divergence in an island bird: isolation by distance, by colonization or by adaptation? Mol Ecol. 2014;23:1028-39. https://doi.org/10.1111/mec.12672.

8. Losos JB. The evolution of convergent structure in Caribbean Anolis communities. Syst Biol. 1992;41:403-20.

9. Malhotra A, Thorpe RS. Experimental detection of rapid evolutionary response in natural lizard populations. Nature. 1999:353:347-8.

10. Thorpe RS, Reardon JT, Malhotra A. Common garden and natural selection experiments support ecotypic differentiation in the Dominican anole (Anolis oculatus). Am Nat. 2005;165:495-504.

11. Thorpe RS, Barlow A, Malhotra A, Surget-Groba Y. Widespread parallel population adaptation to climate variation across a radiation: implications for adaptation to climate change. Mol Ecol. 2015:24:1019-30. https://doi. org/10.1111/mec.13093.

12. Ecology GPR. Evolution of Darwin's finches. Princeton: Princeton University Press; 1999.

13. Grant PR, Grant BR. 40 years of evolution. Darwin's finches on Daphne Major Island. Princeton: Princeton University Press; 2014.

14. Lamichhaney S, Berglund J, Almén MS, Maqbool K, Grabherr M, MartinezBarrio A, et al. Evolution of Darwin's finches and their beaks revealed by genome sequencing. Nature. 2015;518:371-5. https://doi.org/10.1038/ nature14181.

15. Gillespie R. Hawaiian spiders. Science. 2004;303:356-9.

16. Wallace AR. Island life. London, i-xvii: Macmillan and Co.; 1880

17. Nussbaum RA. Amphibian fauna of the Seychelles Archipelago. National Geographic Society Research Reports, Grants 1633, 1743, 1977 Projects: 5362. 1985.

18. Vidal N, Marin J, Morini M, Donnellan S, Branch WR, Thomas R, et al. Blindsnake evolutionary tree reveals long history on Gondwana. Biol Lett. 2010;6:558-61. https://doi.org/10.1098/rsbl.2010.0220.

19. Davies D. When did the Seychelles leave India? Nature. 1968;220:1225-6. https://doi.org/10.1038/2201225a0.

20. McElhinny MW. Formation of the Indian ocean. Nature. 1970;228:977-9. https://doi.org/10.1038/228977a0.

21. McKenzie D, Sclater JG. The evolution of the Indian Ocean since the late cretaceous. Geophys J Int. 1971;24:437-528. https://doi.org/10.1111/j.1365246X.1971.tb02190.X

22. Dickin AP, Fallick AE, Halliday AN, Macintyre RM, Stephens WE. An isotopic and geochronological investigation of the younger igneous rocks of the Seychelles microcontinent. Earth Planet Sci Lett. 1986;81:46-56. https://doi. org/10.1016/0012-821X(86)90099-3.

23. Mart $\mathrm{Y}$. The tectonic setting of the Seychelles, Mascarene and Amirante plateaus in the western equatorial Indian Ocean. Mar Geol. 1988;79:261-74. https://doi.org/10.1016/0025-3227(88)90042-4.

24. Chatterjee S, Goswami A, Scotese CR. The longest voyage: tectonic, magmatic, and paleoclimatic evolution of the Indian plate during its northward flight from Gondwana to Asia. Gondwana Res. 2013:23:238-67. https://doi.org/10.1016/j.gr.2012.07.001.

25. Gower DJ, Agarwal I, Karanth KP, Datta-Roy A, Giri VB, Wilkinson M. The role of wet-zone fragmentation in shaping biodiversity patterns in peninsula India : insights from the caecilian amphibian Gegeneophis. J Biogeogr. 2016; 43:1091-102.

26. Ali JR. Islands as biological substrates: continental. J Biogeogr. 2018;45:1003-18.

27. Davies D, Francis TJG. The crustal structure of the Seychelles Bank. Deep Res. 1964;1:921-7.

28. Colonna M, Casanova J, Dullo W, Camoin G. Sea-level changes and $\delta 180$ record for the past 34,000 yr from Mayotte reef, Indian ocean. Quat Res. 1996:339:335-9.

29. Rohling E, Fenton M, Jorissen F. Magnitudes of sea-level lowstands of the past 500,000 years. Nature. 1998;394:162-5.

30. Siddall M, Rohling EJ, Almogi-Labin A, Hemleben C, Meischner D, Schmelzer I, et al. Sea-level fluctuations during the last glacial cycle. Nature. 2003:423: 853. https://doi.org/10.1038/nature01687.1..
31. Camoin G, Montaggioni L, Braithwaite C. Late glacial to post glacial sea levels in the Western Indian Ocean. Mar Geol. 2004;206:119-46. https://doi. org/10.1016/j.margeo.2004.02.003.

32. Miller KG, M a K, Browning JV, Wright JD, Mountain GS, Katz ME, et al. The Phanerozoic record of global sea-level change. Science. 2005;310:1293-8. https://doi.org/10.1126/science.1116412.

33. Ali JR. Islands as biological substrates: classification of the biological assemblage components and the physical island types. J Biogeogr. 2016;44: 984-94.

34. Legrand D, Tenaillon MI, Matyot P, Gerlach J, Lachaise D, Cariou M-L. Species-wide genetic variation and demographic history of Drosophila sechellia, a species lacking population structure. Genetics. 2009;182:1197206. https://doi.org/10.1534/genetics.108.092080.

35. Legrand D, Vautrin D, Lachaise D, Cariou M-L. Microsatellite variation suggests a recent fine-scale population structure of Drosophila sechellia, a species endemic of the Seychelles archipelago. Genetica. 2011;139:909-19. https://doi.org/10.1007/s10709-011-9595-8.

36. Maddock ST, Day JJ, Nussbaum RA, Wilkinson M, Gower DJ. Evolutionary origins and genetic variation of the Seychelles treefrog, Tachycnemis seychellensis (Duméril and Bibron, 1841). Mol Phylogenet Evol. 2014;75: 194-201.

37. Adamson EAS, Saha A, Maddock ST, Nussbaum RA, Gower DJ, Streicher JW. Microsatellite discovery in an insular amphibian (Grandisonia alternans) with comments on cross-species utility and the accuracy of locus identification from unassembled Illumina data. Conserv Genet Resour. 2016;8:541-11.

38. Maddock ST, Briscoe AG, Wilkinson M, Waeschenbach A, Nussbaum A Gower DJ. Next-generation mitogenomics: a comparison of approaches applied to caecilian amphibian phylogeny. PLoS One. 2016;11:e0156757.

39. Harris DJ, Perera A, Valente J, Rocha S. Deep genetic differentiation within Janetaescincus spp.(Squamata: Scincidae) from the Seychelles Islands. Herpetol J 2015;25:205-13.

40. Labisko J, Griffiths RA, Chong-seng L, Bunbury N, Maddock ST, Bradfield K, et al. Endemic, endangered and evolutionarily significant: cryptic lineages in Seychelles' frogs (Anura: Sooglossidae). Biol J Linn Soc. 2019:126:417-35.

41. Silva A, Harris DJ, Rocamora G, Dufrenne A, Gerlach J, Rocha S. Assessment of mtDNA genetic diversity within the terrapins Pelusios subniger and Pelusios castanoides across the Seychelles islands. Amphibia-Reptilia. 2010;31: 583-8. https://doi.org/10.1163/017353710X524723.

42. Rocha S, Carretero M, Harris D. Genetic diversity and phylogenetic relationships of Mabuya spp. (Squamata: Scincidae) from western Indian Ocean islands. Amphibia-Reptilia. 2010;31:375-85. https://doi.org/10.1163/ 156853810791769473

43. Rocha S, Rösler H, Gehring P, Glaw F. Phylogenetic systematics of day geckos, genus Phelsuma, based on molecular and morphological data (Squamata: Gekkonidae). Zootaxa. 2010:28:1-28.

44. Rocha S, Harris D, Posada D. Cryptic diversity within the endemic prehensile-tailed gecko Urocotyledon inexpectata across the Seychelles Islands: patterns of phylogeographical structure and isolation at the multilocus level. Biol J Linn Soc. 2011:104:177-91. doi/https://doi.org/10. 1111/j.1095-8312.2011.01710.x/full.

45. Rocha S, Posada D, Harris DJ. Phylogeography and diversification history of the day-gecko genus Phelsuma in the Seychelles islands. BMC Evol Biol. 2013:13:3. https://doi.org/10.1186/1471-2148-13-3.

46. Valente J, Rocha S, Harris DJ. Differentiation within the endemic burrowing skink Pamelaescincus gardineri, across the Seychelles islands, assessed by mitochondrial and nuclear markers. African J Herpetol. 2014;63:25-33. https://doi.org/10.1080/21564574.2013.856354.

47. Daniels SR. Reconstructing the colonisation and diversification history of the endemic freshwater crab (Seychellum alluaudi) in the granitic and volcanic Seychelles archipelago. Mol Phylogenet Evol. 2011;61:534-42. https://doi. org/10.1016/j.ympev.2011.07.015.

48. Taylor ML, Bunbury N, Chong-Seng L, Doak N, Kundu S. Griffiths R a., et al. evidence for evolutionary distinctiveness of a newly discovered population of sooglossid frogs on Praslin Island, Seychelles. Conserv Genet. 2012;13: 557-66. https://doi.org/10.1007/s10592-011-0307-9..

49. Gardner AS. The biogeography of the lizards of the Seychelles Islands. 1986; 13:237-253

50. Nussbaum RA, Wu SH. Distribution, variation, and systematics of the Seychelles treefrog, Tachycnemis seychellensis (Amphibia: Anura: Hyperoliidae). J Zool. 1995;236:383-406. doi/https://doi.org/10.1111/j.14697998.1995.tb02720.x 
51. Rocha S, Perera A, Silva A, Posada D, Harris DJ. Evolutionary history of Trachylepis skinks in the Seychelles islands: introgressive hybridization, morphological evolution and geographic structure. Biol J Linn Soc. 2016; 119:15-36.

52. Rocha S, Perera A, Bunbury N, Kaiser-Bunbury CN, Harris DJ. Speciation history and species-delimitation within the Seychelles bronze geckos, Ailuronyx spp.: molecular and morphological evidence. Biol J Linn Soc. 2016; 120:518-38.

53. Wilkinson M, Mauro D, Sherratt E, Gower D. A nine-family classification of caecilians (Amphibia: Gymnophiona). Zootaxa. 2011;2874:41-64.

54. Maddock ST, Wilkinson M, Nussbaum RA. Gower DJ. A new species of small and highly abbreviated caecilian (Gymnophiona: Indotyphlidae) from the Seychelles island of Praslin, and a recharacterization of Hypogeophis brevis Boulenger, 1911. Zootaxa. 2017:4329:301-26.

55. Maddock ST, Wilkinson M, Gower DJ. A new species of small, long-snouted Hypogeophis Peters, 1880 (Amphibia: Gymnophiona: Indotyphlidae) from the highest elevations of the Seychelles island of Mahé. Zootaxa. 2018;4450: 359-75.

56. Nussbaum R. The amphibians of the Seychelles. In: Stoddart D, editor. Biogeography and ecology of the Seychelles islands. Dr. W. Junk, the Hague; 1984. p. 378-415.

57. Cuvier GLCFD. Le Règne Animal Distribué d'Après son Organisation, pour Servir de Base à l'Histoire Naturelle des Animaux et d'Introduction à I'Anatomie Comparée. In: Nouvelle Edition, Revue et Augmentée par P.A. Latreille. Volume. Paris: Deterville; 1829. p. 2.

58. Brauer A. Beiträge zur Kenntniss der Entwicklungsgeschichte und der Anatomie der Gymnophionen. Zool Jahrbücher, Abteilung für Anat und Ontog der Thiere. 1897;10:389-472.

59. Brauer A. Beiträge zur Kenntniss der Entwicklung und Anatomie der Gymnophonen. Zool Jahrb Anat. 1899:12:389-472.

60. Parker H. Caecilians of the Seychelles Islands with description of a new species. Copeia. 1958;(2):71-6.

61. Taylor E. Caecilians of the world. Lawrence, KS: University of Kansas Press; 1968

62. Taylor E. Miscellaneous notes and descriptions of new forms of caecilians. Univ Kansas Sci Bull. 1969:XLVIII:281-96.

63. Balinsky JB. Adaptation of nitrogen metabolism to hyperosmotic environment in Amphibia. J Exp Zool. 1981;215:335-50. https://doi.org/10. 1002/jez.1402150311.

64. Duellman W, Trueb L. Biology of amphibians. New York: McGraw-Hill; 1986

65. Myers GS. Ability of amphibians to cross sea barriers, with especial reference to Pacific zoogeography. In: Proceedings 7th Pacific science congress Vol IV, zoology; 1953. p. 19-27.

66. Thorpe R. The use of DNA divergence to help determine the correlates of evolution of morphological characters. Evolution. 1996;50:524-31.

67. Thorpe RS, Surget-Groba Y, Johansson H. Genetic tests for ecological and allopatric speciation in anoles on an island archipelago. PLoS Genet. 2010;6: e1000929. https://doi.org/10.1371/journal.pgen.1000929.

68. Rüber L, Verheyen E, Meyer A. Replicated evolution of trophic specializations in an endemic cichlid fish lineage from Lake Tanganyika. Proc Natl Acad Sci. 1999:96:10230-5.

69. Dasmahapatra KK, Walters JR, Briscoe AD, Davey JW, Whibley A, Nadeau NJ, et al. Butterfly genome reveals promiscuous exchange of mimicry adaptations among species. Nature. 2012;487:94-8. https://doi.org/10.1038/ nature11041.

70. Gower DJ, Kupfer A, Oommen OV, Himstedt W, Nussbaum RA, Loader SP, et al. A molecular phylogeny of ichthyophiid caecilians (Amphibia: Gymnophiona: Ichthyophiidae): out of India or out of South East Asia? Proc Biol Sci. 2002;269:1563-9. https://doi.org/10.1098/rspb.2002.2050.

71. Gower D, Bahir M, Mapatuna Y, Pethiyagoda R, Raheem D, Wilkinson M. Molecular phylogenetics of Sri Lankan /chthyophis (Amphibia: Gymnophiona: Icthyophidae), with discovery of a cryptic species. Raffles Bull Zool. 2005;12: 153-61

72. Matsui M, Nishikawa K, Sudin A, Mohamed M. The first karyotypic report of the genus Caudacaecilia with comments on its generic validity (Amphibia, Gymnophiona, Ichthyophiidae). Copeia. 2006;(2):256-60.

73. Wilkinson M, Presswell B, Sherratt E, Papadopoulou A. Gower DJ. A new species of striped Ichthyophis Fitzinger, 1826 (Amphibia: Gymnophiona: Ichthyophiidae) from Myanmar. Zootaxa. 2014;3785:45-58.

74. Gower DJ, Dharne M, Bhatta G, Giri V, Vyas R, Govindappa V, et al. Remarkable genetic homogeneity in unstriped, long-tailed Ichthyophis along 1500 km of the Western Ghats, India. J Zool. 2007;272:266-75. https:// doi.org/10.1111/j.1469-7998.2006.00266.x.

75. Stoelting RE, Measey GJ, Drewes RC. Population genetics of the São Tomé caecilian (Gymnophiona: Dermophiidae: Schistometopum thomense) reveals strong geographic structuring. PLoS One. 2014;9:e104628. https://doi.org/10. 1371/journal.pone.0104628.

76. Wang H, Luo X, Meng S, Bei Y, Song T, Meng T, et al. The phylogeography and population demography of the Yunnan caecilian (Ichthyophis bannanicus): massive rivers as barriers to gene flow. PLoS One. 2015;10: e0125770. https://doi.org/10.1371/journal.pone.0125770.

77. Lanfear R, Calcott B, Ho SYW, Guindon S. PartitionFinder: combined selection of partitioning schemes and substitution models for phylogenetic analyses. Mol Biol Evol. 2012;29:1695-701. https://doi.org/10.1093/molbev/ $\mathrm{mss} 020$.

78. Ronquist F, Teslenko M, van der Mark P, Ayres DL, Darling A, Höhna S, et al. MrBayes 3.2: efficient Bayesian phylogenetic inference and model choice across a large model space. Syst Biol. 2012;61:539-42. https://doi.org/10. 1093/sysbio/sys029.

79. Lewis CJ, Maddock ST, Day JJ, Nussbaum RA, Morel C, Wilkinson M, et al. Development of anonymous nuclear markers from Illumina paired-end data for Seychelles caecilian amphibians (Gymnophiona: Indotyphlidae). Conserv Genet Resour. 2014;6:289-91. https://doi.org/10.1007/s12686-013-0127-y.

80. Hey J. Isolation with migration models for more than two populations. Mol Biol Evol. 2010;27:905-20.

81. Nei M. Estimation of average heterozygosity and genetic distance from a small number of individuals. Genetics. 1978;89:583-90.

82. Pritchard JK, Stephens M, Donnelly P. Inference of population structure using multilocus genotype data. Genetics. 2000;155:945-59.

83. Armstrong C, Richardson DS, Hipperson H, Horsburgh GJ, Küpper C, Percival-Alwyn $L$, et al. Genomic associations with bill length and disease reveal drift and selection across island bird populations. Evol Lett. 2018;2: 22-36.

84. Diniz-Filho JAF, Soares TN, Lima JS, Dobrovolski R, Landeiro VL, Pires M, et al. Mantel test in population genetics. Genet Mol Biol. 2013;36:475-85.

85. Boulenger GA. Catalogue of the Batrachia Gradientia s. Caudata and Batrachia Apoda in the collection of the British museum. Second. London: Taylor and Francis; 1882.

86. IUCN SSC Amphibian Specialist Group. Hypogeophis rostratus. The IUCN Red List of Threatened Species. Version 2014.2. <www.iucnredlist.org>. 2013.

87. Gower DJ, Wilkinson M. Conservation biology of caecilian amphibians. Conserv Biol. 2005;19:45-55.

88. Maddock ST, Lewis CJ, Wilkinson M, Day JJ, Morel C, Kouete T, et al. Nonlethal DNA sampling for caecilian amphibians. Herpetol J. 2014;24:255-60.

89. Sambrook J, Fritsch E. Maniatis T. Molecular Cloning: A Laboratory Manual. Cold Spring Harbor Laboratory Press, Cold Spring Harbor, MA; 1989.

90. Vos P, Hogers R, Bleeker M, Reijans M, van de LT, Hornes M, et al. AFLP: a new technique for DNA fingerprinting. Nucleic Acids Res. 1995;23:4407-14. https://doi.org/10.1093/nar/23.21.4407.

91. Mock KE, Miller MP. Patterns of molecular diversity in naturally occurring and refugial populations of the least chub. Trans Am Fish Soc. 2005;134: 267-78. https://doi.org/10.1577/T04-037.1.

92. Benham J. Genographer version 1. 2001;6:0.

93. Wilkinson M, Sherratt E, Starace F, Gower DJ. A new species of skin-feeding caecilian and the first report of reproductive mode in Microcaecilia (Amphibia: Gymnophiona: Siphonopidae). PLoS One. 2013;8:e57756. https:// doi.org/10.1371/journal.pone.0057756.

94. Stephens M, Smith NJ, Donnelly P. A new statistical method for haplotype reconstruction from population data. Am J Hum Genet. 2001;68:978-89. https://doi.org/10.1086/319501.

95. Flot J-F. Seqphase: a web tool for interconverting phase input/output files and fasta sequence alignments. Mol Ecol Resour. 2010;10:162-6. https://doi. org/10.1111/j.1755-0998.2009.02732.x.

96. Bandelt HJ, Forster $P$, Röhl A. Median-joining networks for inferring intraspecific phylogenies. Mol Biol Evol. 1999:16:37-48.

97. Kumar S, Stecher G, Li M, Knyaz C, Tamura K. MEGA X : molecular evolutionary genetics analysis across computing platforms. Mol Biol Evol. 2018;35:1547-9.

98. Rambaut A, Drummond AJ. Tracer v1.5. 2009;:Available from http://beast.bio. ed.ac.uk/Tracer.

99. Miller MA, Pfeiffer W, Schwartz T. Creating the CIPRES science gateway for inference of large phylogenetic trees. Proceedings of the Gateway 
Computing Environments Workshop (GCE) New Orleans. 2010:1-8. https:// doi.org/10.1109/GCE.2010.5676129.

100. Nielsen R, Wakeley J. Distinguishing migration from isolation: a Markov chain Monte Carlo approach. Genetics. 2001;158:885-96.

101. Hey J, Nielsen R. Integration within the Felsenstein equation for improved Markov chain Monte Carlo methods in population genetics. Proc Natl Acad Sci. 2007;104:2785-90.

102. Bouckaert R, Heled J, Kühnert D, Vaughan T, Wu C-H, Xie D, et al. BEAST 2: a software platform for Bayesian evolutionary analysis. PLoS Comput Biol. 2014;10:e1003537. https://doi.org/10.1371/journal.pcbi.1003537.

103. Elmer KR, Dávila JA, Lougheed SC. Cryptic diversity and deep divergence in an upper Amazonian leaflitter frog, Eleutherodactylus ockendeni. BMC Evol Biol. 2007;7:247. https://doi.org/10.1186/1471-2148-7-247.

104. Sarver BAJ, Pennell MW, Brown JW, Keeble S, Hardwick KM, Sullivan J, et al. The choice of tree prior and molecular clock does not substantially affect phylogenetic inferences of diversification rates. PeerJ. 2019;7:e6334. https:// doi.org/10.7717/peerj.6334.

105. Miller M. Tools for population genetic analysis (TFPGA) 1.3: A Windows program for the analysis of allozyme and molecular population genetic data. 1997.

106. Lynch M, Milligan B. Analysis of population genetic structure with RAPD markers. Mol Ecol. 1994;3:91-9.

107. Miller M. MANTEL-STRUCT: a program for the detection of population structure via Mantel tests. J Hered. 1999;90:258-9.

108. Weir B, Cockerham C. Estimating F-statistics for the analysis of population structure. Evolution. 1984;38:1358-70.

109. Excoffier $L$, Lischer HEL. Arlequin suite ver 3.5: a new series of programs to perform population genetics analyses under Linux and windows. Mol Ecol Resour. 2010;10:564-7. https://doi.org/10.1111/j.1755-0998.2010.02847.x.

110. Felenstein J. Confidence limits on phylogenies: an approach using the bootstrap. Evolution. 1985;39:783-91.

111. Falush D, Stephens M, Pritchard JK. Inference of population structure using multilocus genotype data: linked loci and correlated allele frequencies. Genetics. 2003;164:1567-87.

112. Earl DA, VonHoldt BM. STRUCTURE HARVESTER: a website and program for visualizing STRUCTURE output and implementing the Evanno method. Conserv Genet Resour. 2012;4:359-61. https://doi.org/10.1007/s12686-0119548-7.

113. Evanno G, Regnaut S, Goudet J. Detecting the number of clusters of individuals using the software STRUCTURE: a simulation study. Mol Ecol. 2005;14:2611-20. https://doi.org/10.1111/j.1365-294X.2005.02553.x.

114. Rosenberg NA. Distruct: a program for the graphical display of population structure. Mol Ecol Notes. 2003;4:137-8. https://doi.org/10.1046/j.1471-8286. 2003.00566.x.

115. Nussbaum RA, Pfrender M. Revision of the African caecilian genus Schistometopum Parker (Amphibia: Gymnophiona: Caeciliidae). Occas Pap Museum Zool Univ Michigan. 1998;187:1-32.

116. Statistical Analysis Software (SAS) v.9.1. 2003.

117. Elliot NG, Haskard K, Koslow JA. Morphometric analysis of orange roughy (Hoplostethus atlanticus) off the continental slope of southern Australia. J Fish Biol. 1995;46:202-20.

118. Hammer $\varnothing$, Harper DAT, Ryan PD. PAST: paleontological statistics software package for education and data analysis. Palaeontol Electron. 2001;4:9.

119. Kumar S, Tamura K, Nei M. MEGA3: Integrated software for Molecular Evolutionary Genetics Analysis and sequence alignment. Brief Bioinform 2004;5:150-163.

120. Wright S. The genetic structure of populations. Ann Eugenics. 1951;15:323-54.

121. Spitze K. Population structure in Daphnia obtusa: quantitative genetic and allozymic variation. Genetics. 1993;135:367-74.

122. Mantel $\mathrm{N}$. The detection of disease clustering and a generalized regression approach. Cancer Res. 1967;27:209-20.

123. Sokal R, Rohlf F. Biometry. 3rd Edition. W. H. Freeman and Company, New York; 1995.

124. Oksanen J, Kindt R, Legendre P, O'Hara B, Simpson GL, Solymos P, et al. The vegan Package - Community Ecology Package. October 2016;2008:191.

125. R Core Team. R: a language and environment for statistical. computing. 2014; http://www.r-project.org/

126. Peakall R, Smouse PE. GENALEX 6: genetic analysis in Excel. Population genetic software for teaching and research. Mol Ecol Notes. 2006;6:288-95.
127. Peakall R, Smouse PE. GenAlEx 6.5: genetic analysis in Excel . Population genetic software for teaching and research — an update. Bioinformatics. 2012;28:2537-9

128. Kimura M. A simple method for estimating evolutionary rates of base substitutions through comparative studies of nucleotide sequences. J Mol Evol. 1980;16:111-20.

\section{Publisher's Note}

Springer Nature remains neutral with regard to jurisdictional claims in published maps and institutional affiliations.
Ready to submit your research? Choose BMC and benefit from:

- fast, convenient online submission

- thorough peer review by experienced researchers in your field

- rapid publication on acceptance

- support for research data, including large and complex data types

- gold Open Access which fosters wider collaboration and increased citations

- maximum visibility for your research: over $100 \mathrm{M}$ website views per year

At BMC, research is always in progress.

Learn more biomedcentral.com/submissions 